\title{
THE LANDSCAPE OF INTERNATIONAL COMPUTING
}

Edward M. Rochet

Seymour E. Goodman

Hsinchun Chen

The University of Arizona

Table of Contents

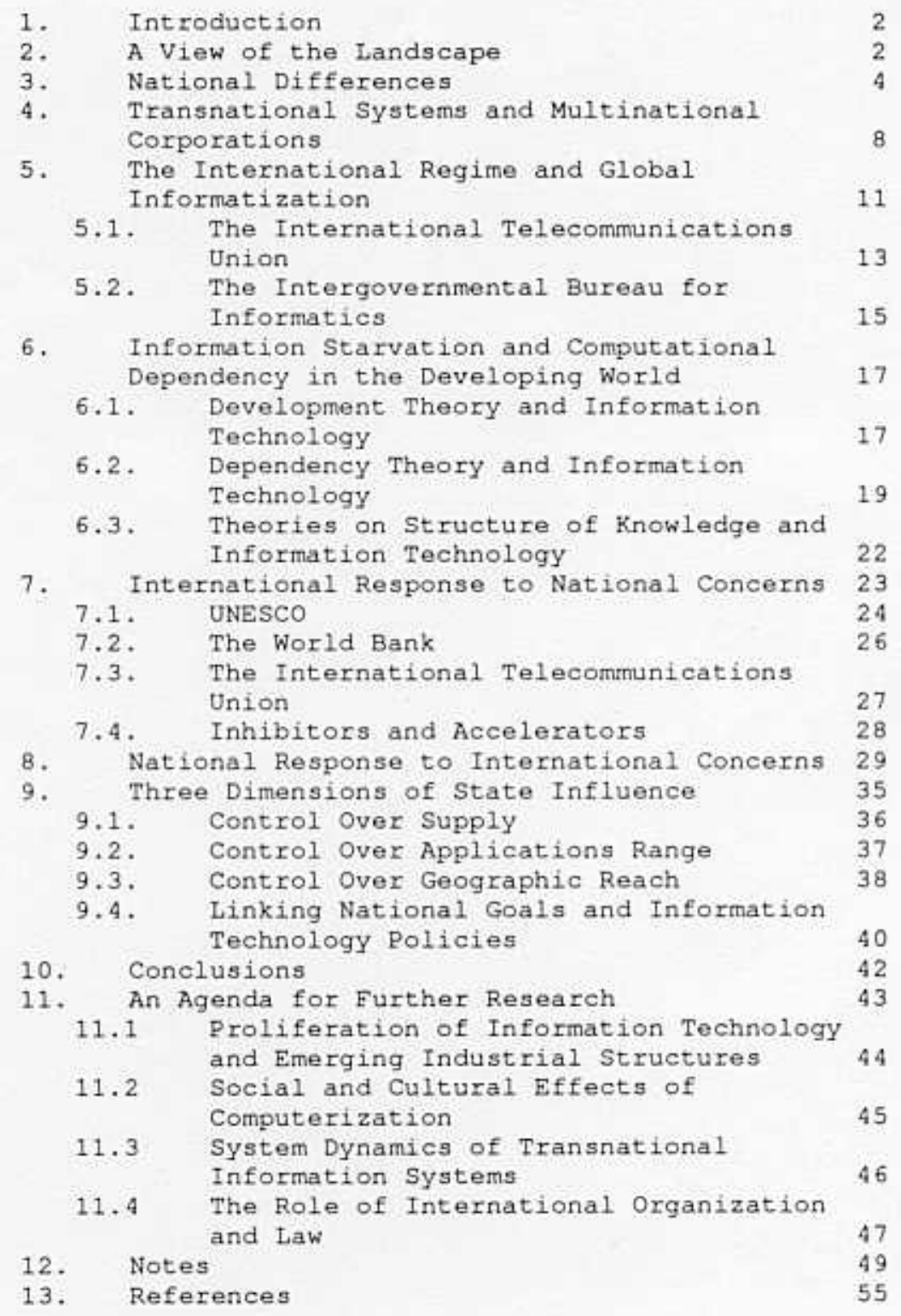




\section{INTRODUCTION}

The landscape of international computing is highly diverse from country to country, reflecting national differences and cultures. In addition, developments at the international level such as the post-war liberalization of international trade, and the activities of the ITU, UNESCO, the IBI, WIPO and other international organizations have done much to aid the global proliferation of information technology. However by the end of the 1980s, the world system was centralized in terms of innovation and manufacturing of information technology, and actions taken to rectify this inequality between nations were ineffective. Dependency theory, development theory and structuralism have all made contributions to understanding the effects of this global inequality and nation states have responded to this inequality according to both their economic status and their relative place within the worldwide system of innovation, manufacturing, and utilization of information technology. They have responded by throttling the supply of information technology within their borders, its geographic reach, and its applications range. These actions, combined with the underlying economic development of the nation state, help explain the vast differences and variations we find in information technology around the world -- they help to explain the landscape of international computing. Much empirical research needs to be done to more fully understand these variations.

\section{A VIEW OF THE LANDSCAPE}

In the computer programming room of a small heavy industry manufacturing firm in seoul, the programmers are huddled. around a burning kerosene stove to keep warm from the bitter Korean winter. The floor is hard dirt and some concrete. The smoke stack from the heater is suspended to the ceiling 
and out a hole punched in a window. The IBM 3270 terminal is next to the stove and its wires run along open on the floor to the mainframe computer room behind screen porch doors covered with hastily stapled plastic sheets to keep out the dust.

Meanwhile, in Stockholm, a member of the staff from the government data ombudsman sends people from the room while inspecting computer records of an employee who is 'deviant'. The government is inspecting the computer-based data files to ensure that no error or distortion has taken place, and that the rights of the individual are not violated through abuse of an information system.

At the same time in Johannesburg a white "European" information worker logs into an IBM mainframe computer to check the work permits and job history of a Zulu "native" who has been caught in an all-white area without proper work papers. The information system is a great help for the policy of apartheid. With so many "native" workers, it is impossible to maintain the system through paper-based bureaucracy.

In Rio de Janeiro, an engineering firm's employees are using Brazilian terminals to interface to the company's minicomputer which has been reverse engineered from a Data General machine. They are working on designs for the Itapu dam, the largest hydroelectric complex in the world. Their terminals are straining the eyes of the predominantly female information workers, but there are no complaints. People are happy with their relatively well-paying and prestigious jobs as data entry clerks. They know the equipment may not be the best, but it is Brazilian-made and in their view it is very important for Brazil to develop its own information technology industry.

In Abu Dhabi, a Caterpillar D-10 needs a replacement valve for a large scraper control. A parts technician logs onto a global database and locates the nearest part in Rotterdam, then orders it placed on the next flight to the Middle East. 
In mid-town Manhattan at 7:35 a.m. a foreign exchange trader is glued in front of several computer screens, busy sending buy and sell messages to other traders in other parts of the world. The trader is playing a risky game of cat and mouse; trying to offer bait of a few million Deutschmarks to a Hong Kong-based trader. The traders are psyching each other out as if they were in the same room, but in fact they are in different parts of the world.

In Bucharest, Romania a completely operational IBM 360 model 40 is busy running one batch job after another, just like the 1960s. The machine was produced a quarter of a century earlier and the installation is 22 years old. 1

A visiting scholar in Ghana is having trouble placing a telephone call to a nearby research institute only 12 miles away because someone has stolen the copper wiring from the telephone poles throughout the city in order to beat the copper into attractive jewelry. ${ }^{2}$

\section{NATIONAL DIFFERENCES}

All of these examples - and there are many others point to the wide variety of conditions which govern computing and telecommunications in different parts of the world. We would assume that technologies and applications are highly variable, and are very dependent upon the social context into which they are inserted. Differences in the ways computing takes place are dependent upon the cultural and economic condition of the country being considered. So if we thought about the differences in the way computing is done at different geographic locations around the world, then we could look at these differences at the nation state level. Of course the way computing is done may be very similar in a poor part of the United States, such as Appalacia, and an advanced part of a developing country. But when the group of phenomena is thought of on a nation-wide basis, then we could consider an average level of computing sophistication and development, 
and thus we can conveniently settle on the nation state as a unit of analysis for understanding the landscape of international computing. In any case, the nation state level is the only place we could even hope to get reliable data, and even that is sketchy at best.

One could suggest many possible explanations of why international computing systems have developed the way they have. The fact that computing is being inserted into different cultures plays a great role as does the general economic conditions of the host environment into which the information technology is being placed. The way businesses are organized might create a difference, and the overall general intent of the information system varies from one context to another. In addition, underneath it all lies the vast differences in how people view information systems, how they feel about them as they work.

At the heart of culture is the deeper idea about the role of the individual. A theocratic state based on a medieval illusion of a purposeful universe and the "proper" mission of citizens (what to eat, how to act, who to hate, what to think) has some very great differences from a "Silicon Valley" culture of rapid exploratory change, ${ }^{3}$ or from a class-bound or ideology-bound state of "acceptable" consensus found in many European countries. These different ideas about the individual carry over into concepts about privacy and the resulting relationship between data processing systems and the individual.

In many East Asian ${ }^{4}$ countries, the type of secrecy and protection given to personal data in Western Europe appears very prudish. On the other hand, the ability of businesses, governments, and other individuals to obtain personal data on individuals in many East Asian countries appears to Europeans to be reckless and somehow deficient in its estimation of the worth of the individual.

The economic conditions where computing is taking place may also influence the way computers are used. The 
importability of computer equipment is many times different, leading to much higher costs (relative to labor and other factors) and thus to a completely different pattern of utilization as the economics of computing itself is changed.

Beyond the macro-level differences which shape the outcome of computing in different environments, there are the micro-level differences in how the individual views information technology - and here we can again see a lack of uniformity between different peoples in different situations. In some circles, information technology is seen as a beacon of progress, in others it is cursed; in some it is a savior and liberating force for humanity, in others an instrument of rigidity and deadly political repression. Obviously the attitude of a Zulu miner in South Africa towards a mainframebased personnel records system is quite different from that of a young upwardly mobile singaporean foreign exchange trader sitting at a terminal near Raffles. All of these aspects of the individual attitude towards computing have come out at one time or another within the context of various social movements, fads and industrial strategies implemented or contemplated in different areas of the world.

In the Asian developing countries, ${ }^{5}$ information technology is recognized as a force for higher value-added ${ }^{6}$ manufacturing, and thus as a road down which the nation might travel in its rapid development. In the tired and crumbling socialist economies of Eastern Europe, the use of information technology in society was nothing more than another empty promise made by the state - a promise which was never extensively implemented, and the benefits of which never came - at least in the consumer sector. In the scandinavian countries Sweden is the best example - information technology is greeted neither with bubbling enthusiasm nor derogation.? Instead, it is thought of as a tool which although very useful, can have serious social consequences and must therefore be carefully controlled for the public benefit. ${ }^{8}$ In Western Europe, information technology is seen as just 
another technology of development, as part of the industrial landscape of machine tools, integrated manufacturing facilities, and the volumes of trade documentation flowing through the system. A completely contrasting view of information technology is found originating first on the west Coast of North America - the notion that information technology is not a part of the industrial landscape but rather is a destroyer of that landscape, a new social mechanism for liberating the human from the monotony of the industrial society arrangements with all of the restrictions and inflexibility they carry, towards the information society in which information technology is used more as a force for human fulfillment. This view is associated with a type of modern "Silicon Utopianism"9 premised on concepts such as remote work groups, telecommuting, ${ }^{10}$ customizable software interfaces, and "user friendly" computing.

So there is a vast amount of study which can be done of differences in the texture of computing at the national level. This type of study is almost a form of "computer anthropology" as these differences are certainly caused in great part by the variations we find in levels of economic and cultural development, and within the enduring context of national differences. Therein lies an entire field of comparative analysis which in general would seek to explain these differences - the texture - in terms of the various contingency factors, such as GNP per capita, cultural patterns, and countless other measurements. But this giant stream of analysis could never reach a complete understanding of the comprehensive phenomena of computing developments, simply because its unit of analysis relies too heavily on the nation state. Information technology has managed to escape the bounds of the nation state and has become an international and global phenomena and accordingly must be considered at these higher levels as well. 


\section{TRANSNATIONAL SYSTEMS AND MULTINATIONAL CORPORATIONS}

There is a second class of international computing phenomena which take place at the transnational level."1

Examples of transnational computing are seen everywhere: global airline and freight reservation systems, large EDI and value-added networks operating simultaneously in many different countries, manufacturing and inventory control systems being used to coordinate the headquarters-subsidiary and subsidiary-subsidiary relationships of multinational corporations, and countless others. Computing at this level by definition takes place simultaneously in more than one country, and so we cannot depend solely upon nation state level analysis to gain a complete understanding of the dynamics involved. Transnational systems, after all, are to some extent stateless in their operation. If they are cut off in one country, they can grow a network in another as a replacement (providing the underlying business strategy of their hosts do not preclude this).

For the most part, transnational systems have been created under the aegis of the multinational corporation, a form of economic organization which has been around for several hundred years, but which has reached its greatest popularity as an object of scholarly research only in the post-war period, with most substantive research beginning in the $1970 \mathrm{~s}$. Many multinational corporations have operations in more than 100 countries, and with no known exceptions, these operations are underpinned by vast electronic networks of computer and telecommunications systems. The annual revenues of a number of MNCs are greater than the entire GNP of most of the countries in the world and, if one considers that multinationals account for more than 70 percent of all world trade, and that their expenditures on information technology are between two and five percent of their revenues, depending on sector, then it is easy to see that these transnational information systems are a powerful force, perhaps even the 
single most powerful force, in shaping global development of computing utilization. ${ }^{12}$

There are other important types of international information systems such as global military command and control networks, inter-governmental networks, and information systems within various international organizations themselves. In addition, there are various cooperative-type transnational computing systems which act as intermediaries between different organizations. For example, Tymnet, Telenet, the Society for Worldwide Interbank Einancial Telecommunications (SWIFT), and GEISCO all act as vast transnational computing and communications systems which intermediate between third parties linking together their operations around the world. In addition, educational and research networks such as Arpanet, bitnet, and internet provide a vast virtual space for inter-organizational communications. However, in terms of the installed base, in other words, in terms of their gross size, (NB: net geographical scope) they are a small fraction of the bulk of transnational computing systems. There are but a score or so such systems, while there are hundreds of multinational corporations, each with dozens or even hundreds of data processing centers and multiple networks; and therefore at the transnational level, the dominant framework of analysis must rely heavily upon the multinational corporation and how it has grown and developed and thereby helped to create the vast array of transnational computing systems which we see before us.

We can identify at least four major uses of information systems in multinational corporations. ${ }^{13}$ These transnational computing systems are used, as mentioned, to coordinate operations between the headquarters and subsidiaries and from subsidiary to subsidiary as well. This means, in effect, that the information system is used to process financial reporting information for purposes of consolidation, to coordinate the distribution of information which must be used in manufacturing and control of inventory, in some cases to 
broadcast important CAD/CAM information from design centers to manufacturing facilities, and also to coordinate between foreign subsidiaries and their inventory control centers. A second important role is providing corporate intelligence and market monitoring systems. The top managerial leadership of the multinational corporation must constantly monitor developments in the various host countries in which it is doing business and scan for economic, political, cultural, technological, and market opportunity information in order to plan and implement the global strategy of the business. Although in the past, the corporate intelligence function within the MNC was not well developed, with the growing internationalization of business in the 1980s, the corporate intelligence function has started to rely more and more on information technologies such as email, teleconferencing, facsimile, and sophisticated modeling in order to perform its function. A third major function of transnational computing systems is to provide information technology-based firmspecific advantages (FSAs). These might be thought of as arrangements of information systems which give the MNC an advantage over its competitors - other multinationals and the domestic competitors encountered in each national market. Finally, transnational computing systems are used to promote the internal economic efficiency of the multinational corporation, most of which is done through the internalization of transactions in such a way as to make them more efficient than the general market. This important role of information technology helps provide the internal engine of accumulation for the multinational corporation, and thus helps it to continue its existence as a sovereign transnational economic actor able to transcend the boundaries of the individual nation state.

The expansion of the MNCs and their international computer networks has been facilitated in great part by the system or regime of international organization, law and practice of the post-war period. It has been a relatively 
liberal system, historically speaking, and that liberalism, combined with the great advances in technology, including computer and telecommunications systems, has allowed a boom in international trade and diffusion of information technology throughout most of the world, although as we will see it has been highly skewed in favor of the developed industrialized countries to the possible detriment of everyone else.

\section{THE INTERNATIONAL REGIME AND GLOBAL INFORMATIZATION}

The wartime devastation to the European infrastructure followed by the dollar shortage drove U.S. multinationals to set up operations in Western Europe. The resulting interpenetration of the world's major economies broke the back of the mercantile practices which had been pursued earlier - practices which automatically would have called for autonomous manufacturing of information technology (if it had been invented at that time). As the international trading regime developed, particularly after the liberalizations of the GATT in the Kennedy Round, following the failure of the

International Trade organization (ITO), ${ }^{14}$ it also did much to ease the spread and diffusion of information technology. For example, IBM's World Trade Organization was set up very early in the $1950 \mathrm{~s}$ and gave Big Blue a commanding and dominant lead over its competitors which is beginning to fade only now, almost half a century later. Besides the group of computer manufacturers in the U.S., several European companies jumped into the act, including ICL of Britain and CII in France. So the liberal trading regime and economic recovery in the postwar period did much to allow global diffusion of information technology as the major vendors set up manufacturing operations and began to market in various countries around the world, in great part to service the parallel expansion of multinational corporations. 
However, as we survey the post-war period, one can see other major influences which have helped information technology spread as it has. The entire system of international organization - in addition to the GATT - has done much in this regard. Apart from general bilateral treaties binding specific states together, ${ }^{15}$ the most potent embodiment of international law is made real by the various international organizations which act as global coordinators and facilitators for the nations of the world. Most of these international organizations form part of the United Nations system. ${ }^{16}$ They are themselves embodiments of multi-lateral treaties, and exist solely because the nation state is willing on occasion to voluntarily yield its sovereignty in order to obtain agreement which improves its opportunities in the international environment. ${ }^{17}$

As we survey the large number of international organizations $^{18}$ which have exercised decisive influence in the development of international computing, ${ }^{19}$ we find that the specialized agencies within the United Nations system have done the most to promote or facilitate developments in international informatization. These specialized agencies cover almost all international actions - from war and peace to refugee operations to postage to health and agricultural assistance programs. However, we are concerned here with only those parts of this vast international machinery of specialized agencies which influence the landscape of international computing, the diffusion of information technology, and the development of the varied system of agreements which underlie its penetration of the world system. ${ }^{20}$ The vast bulk of international computer networking involves building linkages through the media of the international telecommunications infrastructure - communication satellites, undersea fiber optic cables, terrestrial cables, radio transmission, etc. - a system of arrangements the standards of which are set by an important specialized agency - the International Telecommunications Union (ITU). 


\subsection{The International Telecommunications Union}

The International Telecommunication Union, headquartered in Geneva, was founded at Paris in 1865 under the name "International Telegraph Union." It changed its name to the ITU in 1934 when the Telegraph and Radiotelegraph Conventions were replaced by the International Telecommunications Convention which was signed in Madrid in 1932. This was approximately the time when the technologies of radiotelegraph and telegraph were merging together. The sinking of the Lusitania had emphasized the need for a combined convention, since the sos signals had been ignored because of interference. ${ }^{21}$ After the Second World War, the ITU was recognized as a specialized agency of the United Nations.

The ITU has several major functions: it allocates the frequency spectrum for telecommunications, 22 works to help eliminate radio interference between different broadcasters, and helps in fostering the lowest possible charges for international telecommunications, although there is criticism that it has acted as a social club for the monopolistic telecommunications providers enabling them to grossly overcharge for their services. ${ }^{23}$ Some of its most important work takes place through two of its permanent organs: the International Telegraph and Telephone Consultative Committee (CCITT), and the International Radio Consultative Committee (CCIR). ${ }^{24}$ It is within these two committees that the international community establishes the important standards which go far towards increasing the transparency in building international computing systems. ${ }^{25}$ These standards make it possible for computer equipment manufactured in one part of the world to work effectively in another. They provide the important technical context in which international systems are built, and in so doing they are a strong force accelerating the spread of information technology around the world.

These agreements, such as the popular X.25 standard for packet-switched networks, or the international dialing stan- 
dards which ensure that telephone calls are routed properly through the world's telephone systems or that answering machines in one country will respond to the tones generated by telephone sets in another, are all negotiated through the ITU. In addition, allocation of frequencies for radio and satellite communications is handled this way. In its work, the ITU operates a vast system of committees which in turn interact with the many professional bodies found in each nation.

International professional societies such as the IEEE ${ }^{26}$ have taken a leading role in promoting the key technical standards which have made possible the creation of globespanning computer networks. The International

Telecommunications Users Group (INTUG), which is coordinated through the International Chamber of Commerce and its affiliate national chapters, acts as a voice for large users of international telecommunications and information systems. The International standards organization (ISO) and, in the United States, the American National Standards Institute (ANSI) and other organizations such as the Electronic Industries Association (EIA) and various technical and standards subcommittees with individual working groups have all acted as important facilitators in reaching the international understandings which make possible the global diffusion of information technology and its use. When this vast organizational structure of contacts in the United States is allied with similar sister structures in other countries, a powerful informal network is set in motion, and it is indispensable in facilitating the work of the ITU.

The World Intellectual Property Organisation (WIPO) has also played a major role at the international leve1. ${ }^{27}$ As of the late 1980s, WIPO was still grappling with the complex issue of intellectual property rights for software and microchip-embedded code and related technologies, the protection of which was very much a developing area of international law, ${ }^{28}$ vital for helping ensure that vendors take the 
risks involved in international diffusion of their products. In addition, it has worked hard to allieviate the massive problem of software piracy found in many parts of the world.

\subsection{The Intergovernmental Bureau for Informatics}

Another international organization which has been prominent in the post-war period is the Intergovernmental Bureau for Informatics (IBI). Based in Rome, it was an intergovernmental organization ${ }^{29}$ set up in the early 1980 s as an offshoot from UNESCO. At the time of its creation, UNESCO was at the center of the battle over the New World Information Order (NWIO) in which the western industrialized countries were pitted against the developing nations, as symbolized by the Group of $77^{30}$ who were demanding more equal global distribution of information and information technology resources a type of "information welfare program" for the developing world.

In contrast to the heated debate taking place within UNESCO (see below), the philosophy of IBI envisioned many positive benefits of information technology and also envisaged a large role for the private sector, particularly on the part of various vendors. The IBI wanted to launch a series of experiments which would prove the benefits of information technology to many developing countries and it tried (unsuccessfully) to avoid the heated rhetoric of confrontation between the developing countries and the western industrialized countries.

During its lifetime ${ }^{31}$ the IBI was one of the most active international organizations in promoting the utilization of information technology systems in developing countries. ${ }^{32}$ By the time it reached the peak of its power and influence in the early 1980s, it had held several well-attended worldwide conferences on developmental informatics, 33 had launched several publications, and had carried out various experiments in Africa and Latin America focused on showing the benefits 
of novel approaches to information technology including mobile VSAT terminals. ${ }^{34}$

IBI acted as a positive force for the spread of information technology in developing countries and for a while was a counter-force against the dogmatic and antiwestern line which continued to flow out from the ideologues within UNESCO under the leadership of $M^{\prime}$ Bow, who had become bogged down himself in conflicts with the western powers over budget excesses and management practices, particularly nepotism. Unfortunately, it was the IBI and not UNESCO which eventually fizzled and collapsed in financial and personal scandal.

The IBI had been the only international organization ever created for the sole purpose of promoting data processing and telecommunications systems within developing countries. For many, it had acted as a facilitator of information technology diffusion; and for others it had served as a conscience regarding the tremendous task which lies ahead in promoting a "global village." Ultimately, in the grand scheme of things, however, its total impact was small and its collapse was a loss for international scholars, as the disposition of its archives is unclear.

But in spite of these and other efforts which have been made in various international organizations to promote information technology around the world, there has been a growing awareness that the unequal distribution of wealth between the developed and developing countries has been reflected in information technology, and just as many people of the world live in poverty, with poor medical facilities, lacking education, and suffering from inadequate transport, etc., so too have they been unable to enjoy the benefits of the so-called "information revolution," which after all is a "revolution" that has taken place in only a handful of countries around the world. As this awareness took hold, the global distribution of information technology became wrapped up in broader issues of inequality between nations, charges of neocolonial- 
ism, and fears of a type of neo-imperialism based on technology, which schiller termed "electronic colonialism."35

\section{INFORMATION STARVATION AND COMPUTATIONAL DEPENDENCY IN THE DEVELOPING WORLD}

In both academic circles and international organizations the specter of unequal distribution of wealth and information technology resources grew and developed into a wide-ranging debate which touched very broadly upon the international economic, technological and cultural relationships between the developed and the developing nations.

From this debate, several major streams of theory have emerged in the past few decades attempting to explain how information technology is different across cultures, and how it produces effects in the international system. Development theory has dealt with the question of economic development of whole countries; dependency theory has raised many important cultural and ethical issues regarding the global proliferation of information technology and the degree to which this process is equal and just; and theories such as structuralism have raised questions about how information technology is changing how we think about and perceive reality, and warned about the danger of these "idea structures" being imposed by other cultures, e.g., by developed countries upon technologically weaker developing countries.

\subsection{Development Theory and Information Technology}

Development theory ${ }^{36}$ has examined the role of information technology within the context of nation building and infrastructure development primarily in developing countries. ${ }^{37}$ Development theory as a whole came out immediately after the wave of decolonization which swept through the world, particularly Africa, in the 1960s. ${ }^{38}$ The crumbling European empires left in their wake a legacy of under-development, as the structure of unequal production and exchange was bared for 
al1 to see. ${ }^{39}$ In retrospect, it seems as though many countries attempted first to replicate in a short period of time the infrastructures found in their former metropole, without too much regard for economic rationality. When this clearly became impossible, development theory, a system of ideas showing how countries could pass through stages on the way to being advanced, provided an element of rationality and even hope to the frustrations of the underdeveloped.

Development theory was based on engineering investments so that they would follow the same historical pattern as had existed in the developed world as it had developed, only it would be considerably faster. ${ }^{40}$ Natural resources would be developed, then infrastructure and human resources. Gradually, more advanced forms of technology would be imported, and the developing country would climb to higher levels of value-added and wealth creation, thereby raising its standard of living, and so on.

Information technology was never a major part of this picture - at least not until the mid- to late-1980s. Instead, development theory concentrated first on building infrastructure projects, the result being some of the greatest boondoggles in history. ${ }^{41}$ Some countries attempted to work on integrating themselves into the global information technology manufacturing system, and a few, such as several Pacific rim Asian developing countries (e.g., Singapore) succeeded; but most failed, and some never really tried.

Within the context of classical development theory, the place of information technology is ambiguous, but is linked through telecommunications to a recognized part of the critical mass infrastructure needed to get a country moving along the path of development. These ideas were tested somewhat by the Intergovernmental Bureau for Informatics ${ }^{42}$ before its demise.

There are limitations to the development model in terms of how it addresses the issue of global computing developments and diffusion of information technology. The theory's 
limitations preclude its being used as a general model in and of itself. First, it focused specifically on problems of unequal development and thereby drew the debate into a confrontation between developed and developing countries. Its unit of analysis is the individual nation state, usually a post-colonial state; or sometimes the integration of states through regional development organizations such as the organization for African Unity (OAU), and it did include some consideration of the transnational dimension, but lacked a discussion of the overall world economic system at the level of detail acceptable to most econometricians. But even more damning is the fact that no discussion of the global aspects of information technology are included except by a very few writers who do not expound received theory.

A second major problem with classical development theory is that it sees information technology as little more than an extension of the telecommunications network which itself is viewed as being only one of many different basic infrastructure items, and by no means the most important one. The effect of this is that although the perspective of development theory is very useful in the examination of information technology development and proliferation at the nation state level within developing countries; it does not allow examination of broader phenomena. It does not have any way to account for the self-contained power information technology has in implanting itself into societal information networks, driven as it is by economic forces based on efficiency improvements, i.e., the theory is really not intended to be a technology-specific domain of analysis.

\subsection{Dependency Theory and Information Technology}

We do however find a broader picture relating information technology to the overall global system and showing its effects in dependency theory which purports to show how the colonial system of unequal exchange has managed to stay in- 
tact even though the many colonial territories have become independent nation states. Under this model, which is a general political economy model having nothing to do per se with information technology, almost any manufacturing and raw material processing system can be shown to have a production chain organized so that the bulk of the value added is captured by the former colonial power, much to the detriment of the former colony. This is usually called neo-colonialism and is the sequel to the real colonialism which has vanished in most places.

Although neo-colonialism was discussed in industry after industry, it was not until the very late 1970 s and early 1980 s when attention turned to mass media, then inevitably to information technology. ${ }^{43}$ Dependency theory in this context has taken a view of information technology as a mechanism to reinforce an unequal division of labor in the world system. Some critics related this to a view of telecommunications in Africa being defined by the relationship between the metropole and colonial dependency, and gained fame by pointing out that it was always easier to place a long distance telephone call from the former colony to its metropole than to an adjoining state. ${ }^{44}$ The Turn mode ${ }^{45}$ viewed processing of information and data from developing countries as similar to the looms of Manchester weaving Indian cotton for resale in that same market. Instead of examining raw cotton, one examines raw data; instead of looms, computers; instead of finished woven goods, information-based products - all at unequal terms of trade for the developing country. All of the value added and profit had been kept within England and its textile community; and in terms of information technology, developing countries are constantly at a disadvantage in terms of trade in information, knowledge or data, and this would allow a new "global dark ages" to descend upon the world. ${ }^{46}$ The implication of the argument is that unless developing countries either obtained or developed their own computing capacity, they would be permanently locked into an 
unequal relationship. They would remain "hewers of wood and carriers of water."

Besides the question of unequal development, some dependency theorists took a more sober and chilling view of the global spread of information technology. They viewed it as being almost part of a conspiracy to brainwash weaker populations into permanent relationships of dependency and economic subjugation. ${ }^{47}$ Information technology is not a neutral force, instead it is a means of locking people into unequal economic relationships by controlling information flows, information access and information processing. Unequal distribution in terms of data processing helps reinforce the overall inequality in economic relations, an inequality in which surplus value is continually drained away as the global process of capitalist accumulation sucks the very blood of the weaker country, the result being that the more they develop along this path, the relatively weaker and poorer they become, and the less freedom they have to maneuver.

These writers were as much horrified by the emerging power of information technology as were supporters excited by the rapid treks down the price performance curves for most components and hardware systems. ${ }^{4 B}$. Where some saw advantages and more efficiency in data processing, others saw a creeping force which was threatening and which had to be stopped at any cost.

The practical result of much of this thinking was the slow acceptance of information technology into many societies, particularly into Latin America. In countries such as Brazil, for instance, information technology was accepted, but not on the terms being offered initially, and the success Brazil had experienced in the petrochemical industry ${ }^{49}$ led the Brazilian government to attempt building a national computer industry (as it had in petrochemicals), thereby locking out foreign manufacturers from the market. The search for autonomous manufacturing and technological independence could be pursued by a country such as Brazil which has a large in- 
ternal market, 50 but this option is available to only a handful of developing states. ${ }^{51}$

\subsection{Theories on Structure of Knowledge and Information Technology}

There is another view which focuses more on the effects of information technology, particularly on a country's culture. This alternative view has concentrated on deeper questions about the very structure of knowledge and ideas. It attempts to explain how the mental categorization and comprehension of information and knowledge is altered by the enforced rigidity of information technology. In this view, the rise in the power and distribution of information technology is seen as being a type of standardization in which knowledge and ideas are force fitted into the filing and partitioning structures of the computer database. It is agreed that the advantages in doing this are great - the efficiency, the transportability, the formalized logic and thus the ability for knowledge to be passed from one to another over great expanses of time, etc. But the complaint comes when cultural differences and historical traditions are taken into account.

The French argued, for example, that the way information regarding French history had been structured and indexed in the Lockheed Dialog database, which originated in a "foreign culture" (the United States), was not the same as would have been the case if it had been done in France, using a French sensibility. Instead, databases about France sold through Lockheed Dialog and delivered across the vast expanse of the world's packet-switched networks were being structured in a way which was "non-Erench". As a result, any person in France wishing to conduct research with the database would be forced to work with an alternative and essentially foreign way of thinking about information. ${ }^{52}$ The idea suggested that the underlying structure of some databases would bias the view of the world taken by those researchers and thus corrupt 
their scholarship and warp their thinking. Although based on a very sensitive response to an almost esoteric issue, the complaint raised serious and valid questions. These debates hoisted up the highly irascible banner of French culture and identity and increased pressures for protectionism against 'foreign' data and information pouring into France and polluting the structural access patterns of its information landscape. This argument in the past had been much more mass media-oriented, but its application to computer-held data was based firmly in the intellectual tradition of Levi-strauss and French structuralism. This time the invader was invisible, it was a way of structuring information itself, but it was still viewed as being a great threat to French culture and identity. ${ }^{53}$ Writers such as Mattelart took up the same issue but within the context of the Third World. ${ }^{54}$

In any case, the picture which emerges is that information technology seems to have all of the following characteristics, some contradictory. It can be a corrupting force which destroys traditional forms of work and social arrangements in weaker cultures; it can act as a carrier of "alien" idea structures which mercilessly re-shape the cognitive and physical patterns of information processing in the social unit into which it is inserted; ${ }^{55}$ and it can act as a powerful tool reinforcing systems of economic inequality and exploitation and domination while at the same time providing great advances in efficiency and ease of communication.

\section{INTERNATIONAL RESPONSE TO NATIONAL CONCERNS}

These concerns were taken up in the early $1980 \mathrm{~s}$ at the international level in UNESCO and the World Bank (International Bank for Reconstruction and Development), but with completely different results. UNESCO tended to take a neo-Marxist line heavily oriented towards underlying assumptions about dependency in the international system, and the injustices which are perpetrated against the less fortunate 
developing nations. The World Bank, on the other hand, tended to work hard at changing its funding priorities towards more development assistance in informatics, particularly as regards the telecommunications infrastructure. Even the ITU, which for years had prided itself on being "non-political" eventually became embroiled in the debate.

\subsection{UNESCO}

The United Nations Educational, Scientific and Cultural organization (UNESCO), headquartered in Paris, was one of the first organizations to be established in the modern United Nations. It came into being in 1946 at approximately the time the UN Charter was signed in San Francisco. It is one of the more general of the international organizations, and it has developed a very "soft" agenda in regards to the worldwide spread of information technology, in the sense that it is not technically but rather culturally oriented. UNESCo has possibly the broadest charter of any international organization. It is concerned with contributing to international peace and security by promoting collaboration in education, science, culture and communications. ${ }^{56}$

UNESCO has been very active in promoting communications systems for the "free and balanced flow of information for the universal pooling of knowledge" and worked hard in promoting the New World Information order - a concept in which information and communications and the technologies which process them would be distributed throughout the world in accordance with broad principles of equity. In the $1980 \mathrm{~s}$ in UNESCO, very serious questions were raised about the advantages and disadvantages of information technologies and the debate immediately ran into serious trouble when the international mass-media was criticized as giving unbalanced and biased reporting concerning events in developing countries. ${ }^{57}$ The many issues raised included controls over transborder data flows, the use of information technology to increase de- 
pendency or to foster the continued existence of an unequal economic exchange as reinforced through the international division of labour, the unfair use of data and information collected from developing countries by organizations in the developed world which had the means (i.e. computer equipment and systems) to process and understand the information, the lack of human rights as regards information stored in databases, particularly when those databases were located outside of the confines of the developing country, and so on. The result of these and associated debates was to raise a serious question mark regarding the advantages of information technology in developing countries. UNESCO circles managed to form a dark cloud over the "information revolution" being promised by computers and their advocates, and they did not support the head-long rush towards international free trade and free utilization of information technology, particularly when "free use" meant that foreign multinational corporations could do as they wished with information technology in the developing world without regard to the social consequences. These concerns on the part of the international community, as expressed by the majority votingss rule which favored the more numerous developing countries, only served to reinforce and provide rationalization for the many types of controls which were in place at the nation state level, particularly in non-democratic regimes around the world, the result of which appears to be some inhibition in the spread of information technology on an international basis, ${ }^{59}$ although no one has been able to precisely measure this. In any case this debate certainly served to legitimize state intervention in the informatics sector, and even today the world is still dealing with the consequences.

Although the UNESCO debates raised issues about the equality of distribution of information technology, and although these concerns were echoed in the many national policies which restricted this distribution, the outcome of these concerns was quite different elsewhere at the international 
level. In the World Bank for instance, controlled as it is by a different voting structure, the "information revolution" encountered a much more pragmatic attitude.

\subsection{The World Bank}

The World Bank is composed of three institutions: the International Bank for Reconstruction and Development (IBRD), 60 the International Development Association (IDA), and the International Finance Corporation (IFC).

originally, the World Bank was intended to help in financing different infrastructure projects around the world. With the wave of famines and other problems which swept through the developing world in the post-colonial period combined with recession and the international credit crisis, the World Bank gradually narrowed the beam of its efforts towards projects which are targeted at only the very poorest countries in the world, 61 where it works closely with the United Nations Development Programme (UNDP).

In the early post-war period, its concept of infrastructure did not include information technology as a separate and definable component. Instead, the Bank was concerned with items such as roads, bridges, port facilities, agricultural processing facilities, mining, and similar basic industries. Telecommunications issues were covered through other specialized agencies of the United Nations such as the ITU, although in the early post-war period, neither did the ITU target development and technical assistance so specifically to developing countries. Gradually, by the early 1980s, the Bank began to take a great interest in the role of the computer, electronics, and information processing industry sector in different developing nations. ${ }^{2}$ As the importance of information technology in the economies of the developed nations became even more clear, reaching as it did almost 50 percent of capital investment expenditures in the United States by the end of the 1980s, the development priorities of the Bank 
changed to encompass even more work in this area. ${ }^{63}$ Telecommunications was recognized as being one of the most critical elements of infrastructure development, ${ }^{64}$ whereas in the past it had been an afterthought. In addition, studies of the economic effects of computerization, and assessments of different industrial policy strategies which might be followed by different developing countries, were all examined by the Bank. By the early 1990s, analysts in the Bank were writing about "information poverty" and a "new technoeconomic paradigm" in which "the most widespread benefits for developing countries are likely to come from the effective application of informatics in priority sectors." 65

\subsection{The International Telecommunications Union}

The ITU, on the other hand, had worked at its original mission of technical coordination fairly successfully until the 1970s when the developing nations of the world began to take a considerably stronger position in various international fora. ${ }^{66}$ Although ideally, particularly in the early stages of the life of the ITU, international telecommunications had been seen as being economically and culturally neutral in its orientation; these new nationalistic elements injected into the international system, and thereby gaining a majority of voting seats, saw things quite differently. One of the first big conflicts came over the New World Information order in the 1970 s and early 1980s, when many of the more vocal and radicalized nations, such as Cuba, ${ }^{67}$ began to demand a reallocation of the frequency spectrum based on political rather than technical considerations. ${ }^{68}$ The movement into the political arena came as a big shock to the engineering mind-set of the ITU. It was at first caught off guard, and it took about five years before this new element was accomodated into its decision making routine. The longterm result was that the ITU also began to take a more proactive and developmental orientation in its work, and itself 
became an important pressure group for getting more funding for development of the world's telecommunications infrastructure.

\subsection{Inhibitors and Accelerators}

We can observe from all these examples that the forces of international organization - the ITU, UNESCO, WIPO, the World Bank, and others - have both inhibited and accelerated the emergence of international information technology, and in this sense, their actions, and the intellectual debates which took place in their corridors of power, mirrored the major concerns which were expressed in various nation states.

Many of the key international organizations raised important, but divisive issues for the international community concerning the emerging role of international computing. The possible negative cultural and economic issues have been emphasized as information technology was linked with the continuation of unequal development on the part of the global political economy.

The acceptance of international telecommunications standards had helped build interconnectable telephone networks. Software protection, and registration of patents, provided by organizations such as WIPO, had enabled vendors of information technology to provide near-"universal" service in many countries of the world. Eorceful environmental conditions such as the international trading regime had greatly facilitated international trade and the rapid expansion of the multinational corporations which have come to be the largest users of international computing. ${ }^{69}$

In the end, all of this activity taken together tended to accelerate the spread of information technology in spite of the bickering in UNESCO, and by improving the infrastructure made possible the growth of complex worldwide information systems. It also aided in implantation of information technologies into the cultural environments of many coun- 
tries, regardless of whether or not they were part of a transnational network. So by the end of the $1980 \mathrm{~s}$, information technology and its assorted industries were recognized as being critical for development and the avalanche of computerization continued its uneven spread around the world, to even some of the most remote and unlikely places.

We also see that several major international economic institutions worked hard to incorporate information technology development into the standard orthodoxy of political economy. ${ }^{70}$ Unfortunately, the result has been that in spite of much effort being made to improve conditions in the developing world, information technology development has been forced to compete for resources just like any other sector of the economy in developing countries. ${ }^{71}$

This means, in effect, that the constructive forces of international organization are always relatively poorly funded in comparison to the economic power and technological clout of private sector transnational actors such as the multinational corporations, and as a result they have never been strong enough to act as an effective counter-balance to the generally unequal distribution of wealth in the world. The result is that as with so many other technologies and resources, it is the case that with information technology the centers of innovation, manufacturing, and utilization are not equally distributed between countries, peoples, and regions of the world. ${ }^{72}$

\section{NATIONAL RESPONSE TO INTERNATIONAL CONCERNS}

This global and highly unequal distribution of information technology sets the stage for competition between individual nation states, and for these nations the outcome of the game depends upon the options available and the point from which they are starting. The steep learning curves required in the manufacturing process, and the critical importance of the installed base of a vendor's computers, combined 
with the incredible amounts of capital required for much manufacturing and the vital importance of meeting quick turnaround times as the innovation and product life-cycles compressed all tended to encourage a global concentration of the computer industry, particularly when components are taken into consideration. As a result, the distribution of innovation and manufacturing today is not decentralized, it is centralized in only a handful of countries, and in the early 1990 s it was rapidly becoming most focused in Japan and the United States.

Eigure 1 summarizes the diffusion of information technology, on a nation state basis, according to type of manufacturing (if any) and type of country. The countries are divided up based on the World Bank classifications, ${ }^{73}$ but with modifications. The three major areas for innovation in information technology are the G-7 countries which are responsible for the underlying innovation and manufacturing in basic research and product development. These countries are labeled "innovators" to signify their status. However, because of the special role of the United States and Japan, we have separated the G-7 group into "first tier" and "second tier" with the second tier being reserved for those countries, such as France, Italy, Germany, and the United Kingdom which have significant electronics and data processing industries, but are followers rather than leaders in innovation (at least at this point in history).

Another group of countries, the "East Asian NICs"74 also plays an important role in manufacturing of some components and many sub-assemblies. These countries are aiming to improve their global computing position in the 1990s, have strategically switched their information technology focus to the following areas: (1) total quality control; (2) software development so as to increase investment in software industries and education of software engineers; (3) integrated circuit development through increases in the 
research and development abilities in IC designs;

worldwide promotion of own brand name products. ${ }^{75}$

other countries, such as the middle income countries, which include much of Latin America, the African developing countries, ${ }^{76}$ and the formerly socialist East European countries also play different roles in international computing, but not from the point of view of innovation of the underlying technologies.

In tracing the global pattern of diffusion, we see the basic technologies radiating out to other parts of the world from their source in the first tier innovators who are responsible for both innovation and much manufacturing. Information technology is manufactured in other parts of the world as well, but we classify this as "dependent" manufacturing to indicate the important role of technology licensing from the first tier innovators, the use of large amounts of their components, and the general need to comply with their architectural standards. Dependent manufacturing also takes place through foreign direct investment from the first tier innovators - for example, IBM manufacturers in Western Europe and Brazil. These types of operations are advanced in terms of their technology and the sophistication of their manufacturing processes, but underneath it all, they are controlled by a foreign parent multinational corporation. 77 The fact that many nations specify among key market entry conditions requirements for technology transfer indicates that it does not normally take place. This type of dependent manufacturing is also found in the East Asian NICs, many of which are involved in sub-contracting to foreign multinationals. Even when these smaller countries grow their own companies, for example to manufacture clones of the IBM PC, they are still dependent in terms of architecture designs, innovation, and other factors. They manufacture, but they do not innovate, except to a limited degree, and certainly not in basic research. 
The term "autonomous manufacturing" is reserved for cases in which the industry in a country is not connected to foreign industries by ownership or direct industrial collaboration. One example might be if a country decides to manufacture its own television sets, and cuts off imports in order to protect its domestic industry. In the data processing sector, the Soviet Union and East European countries have built up a large autonomous informatics establishment, to a large extent independent of formal relationships with firms in the innovating countries. ${ }^{78}$ The Brazilians also have adopted an autonomous manufacturing strategy for much of their industry, ${ }^{79}$ and their national goal is aimed at developing the Brazilian economy without becoming dependent upon outside multinational corporations for technology. Even as late as the early 1990 s there was a significant amount of disilusionment within Brazil towards the autonomous development model, and a large amount of outcry against the informatics policy; but in spite of this no reversal in policy appeared on the horizon, so predictions of abandonment of the autonomous development model seemed premature.

The other countries of the world, and these represent by far the majority, are not engaged in either innovation or manufacturing of information technology. They are consumers. Within this group, however, we can distinguish between that consumption of information technology being brought about by the government and public sector or semi-public organizations and economic entities (parastatals) on the one hand; and that consumption being brought about by foreign economic entities, usually multinational corporations, which bring information technology into the country for their own use. In the former case, the cultural characteristics of the host environment play a major role in how the information technology is used, because the organizations into which it is implanted embody the cultural attributes of the host country. In the latter case, however, information technology is intended primarily to support the operations of a foreign economic entity, and 
is thus considerably less susceptible to these cultural influences. This helps explain why the use of information technology in many developing countries appears so highly irregular.

Eigure 1

NATION STATES AND DIFFUSION OF INEORMATION TECHNOLOGY

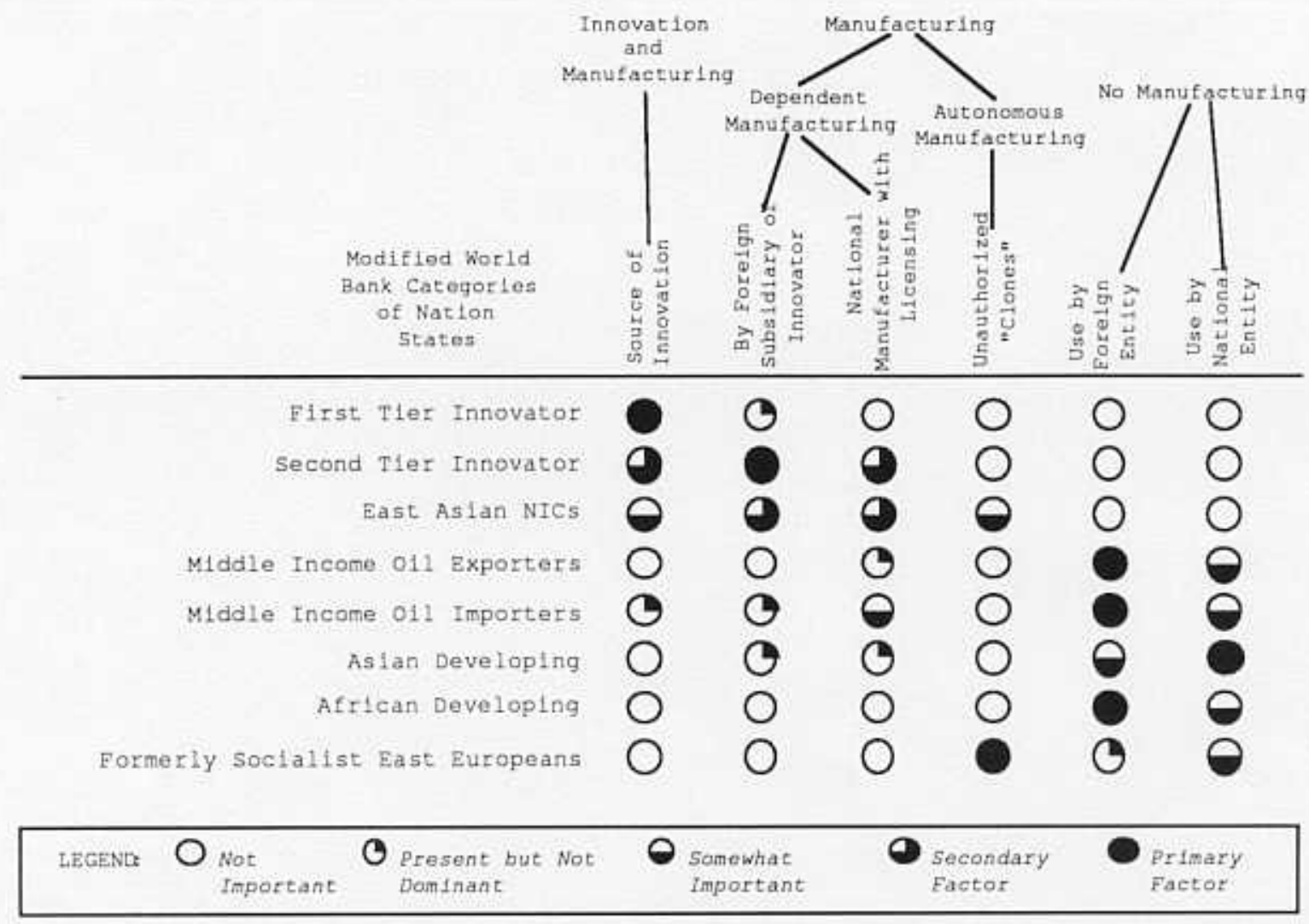

Eigure 1 shows the approximate role of each of these factors in relation to the type of nation state being considered. It is somewhat conceptual for the following reasons: 1) the discussion relates to an entire industry which itself is made up of many parts and these are aggregated together; 2) we know of no published data which describes the economic structure of the entire computer and telecommunications industry according to country as a function of innovation and 
manufacturing relationships; 3) although it is possible to reach an empirical picture of the value-added portion of manufacturing done by domestic companies and foreign multinationals within different countries, thereby getting a precise measurement of the "importance" (see legend) of that arrangement within the overall structure of the industry, this data also is non-existent; 4) in terms of the "no manufacturing" countries, there are no published measurements which purport to show the relationship between the use of information technology by national versus foreign entities; in fact for most countries of the world, there is practically no data at all, on anything relating to these countries; 5) Brazil and India fit into the "dependent manufacturing" category because of their widespread use of licensing and the operations of foreign multinationals; and 6) the East Asian NICs and the formerly socialist East Europeans have a wide-spread use of "unauthorized clones" and there is wide-scale state-supported or -ignored piracy and lack of protection of intellectual property rights. ${ }^{80}$

This framework, although it is hampered by a serious lack of hard data, does lead to a reasonable conclusion that an analysis which matches the economic circumstances in individual countries against the role played by these countries in the overall global structure of the information technology industry would lead to a preliminary understanding of why there are such great differences in utilization patterns from one country to another. Nation states, although at least theoretically sovereign independent political units, are for the most part highly dependent upon the centers of innovation for their supply of information technology. In fact, all of the world and its peoples are highly dependent upon the research and development and manufacturing taking place in a few locations in Japan and the United States. ${ }^{81}$ As a result, nation states find that they are in very different situations vis-a-vis this new technology, and yet computerization is generally recognized as being extremely important to economic 
development and operations. As a result, in most circumstances, formation of some kind of informatics policy either passive or interventionist is forced upon the state. Nations appear to have adopted different policy responses to the "information revolution", depending on their role in the global scheme of things. Some have been promoters of a worldwide free trade regime, particularly when this implied that their industries would be able to export information technology; other have attempted to build up their national computer industries in order to "catch up" with the innovators; others have throttled the growth of information technology utilization in order to prevent the "cultural corruption" which in some quarters it is believed to imply; still others have just imported as much as they needed, without ever worrying about whether or not they should manufacture it. However, regardless of the type of response adopted by the state, any policy can be assessed according to the ways in which state control and influence effects the development and utilization of information technology.

\section{THREE DIMENSIONS OF STATE INFLUENCE}

Regardless of the specific philosophy of the nation state, either by direct action or default, it has a policy towards informatization, and this policy, towards either rejection or promotion of information technology, is carried out through a variety of levers of power. Governments control the importation and exportation of information technology; they determine how computers are taxed and whether they are encouraged or discouraged, not only generally but on a sector-by-sector basis as well. Some governments provide vast subsidies ${ }^{82}$ to their own industries in order to build them up. Others limit the telecommunications circuits which tie systems together or prohibit linkages between domestic and foreign computers. Others regulate standards, control labor availability and cost, even allocate educational and 
training resources which might be targeted at the informatics sector. Governments also control how computers are used: auditing requirements may be stiff, privacy and confidentiality regulations are highly regulated in many markets. The types of programs which must be used for financial reporting and other aspects of computing are also highly varied and unique to each national environment. Some governments scrupulously protect intellectual property rights, others allow massive software piracy and systematic plundering of technology rights. The most comprehensive list we can find describing the different national restrictions is from the United States Trade Representative, and was drawn up as part of the GATT trade negotiations. ${ }^{83}$ It shows the vast array of actions taken by governments in response to information technology and its use. Very much depends upon the power, cohesion, and goals of the nation state. There are many ways in which to classify these actions by the nation state: legal, economic, political, etc.; however, we suggest that if one is to understand their direct effects on information systems, then these controls can be summarized in only three dimensions which describe their effects on the underlying utilization patterns of information technology and its depth of penetration into the society of the nation state. ${ }^{84}$ Our three dimensions of influence are: supply, range, and reach, described below.

\subsection{Control Over Supply}

Many of the actions taken by countries have an industrial policy orientation, targeted at building up the domestic computer industry. These actions have a strong effect on the supply of information technology into the nation state and may greatly inhibit its proliferation. Taxes, tariffs, import controls, foreign exchange controls, etc. are all examples of ways in which countries throttle the development and utilization of information technology. In contrast, 
other policies may accelerate its diffusion. Interestingly enough, these policies either positive or negative are not always aimed specifically at the information technology sector. For example, China restricts importation of information technology at least as much for reasons of foreign exchange shortages than because of some specific philosophy regarding computerization. ${ }^{85}$ Countries such as South Korea are very restrictive about importation of information technology, unless the importer is involved in research and development, in which case there is an exemption of all tariffs. The United States restricts importation of computer technology in cases where intellectual or industrial property rights are being violated. Telecommunications authorities, such as the Deutsches Bundespost, restrict importation of telecommunications equipment which, according to the regulations, must be supplied by approved German industries. There are many examples of how the nation state acts to influence the supply of information technology inside its borders.

\subsection{Control Over Applications Range}

However, once information technology has taken hold within the nation state, there are still other actions which can be taken to control how it is used, i.e., how it is inserted into the local society. In many countries, this choice is a laissez faire one, and there is, as a result, an absence of direct state control. However, it appears that the farther we move away from the centers of innovation, the more extreme become the controls levied by the nation state.

We find many types of nation state control and influence targeted at screening of applications, and how they are used. For example, mailing list applications are not permitted in Sweden, except under very strict government supervision and licensing. Encryption software available in the United States must be licensed for export. Different national regulations regarding human resources and payroll systems may 
make it difficult or impossible to move these applications from one country to another. Many government-imposed industrial policies in the software market prohibit importation of applications for which there is a "substantially equivalent" package available domestically, regardless of the consequences of this regulation on systemwide economic efficiencies in large global systems.

These types of controls imposed by the nation state tend to throttle the applications range ${ }^{86}$ of the information system - allowing it to grow and integrate in certain directions, but not in others. The applications range of an organization increases with the level of integration between different applications and their associated functional areas within the firm. ${ }^{87}$ Controls on development of applications range may act as a severe restraint on the natural growth of the country's information sub-structure, and their impact varies greatly from one national environment to another as they are influenced by economic factors and goals, by cultural values and practices, and by the underlying fit between the specific nation state being considered and the global structure of innovation, manufacturing and utilization of information technology.

\subsection{Control Over Geographic Reach}

A third class of actions by the nation state is aimed at throttling the geographical reach of the information systems. These actions influence how information systems are linked together and interact with one another across substantial distances. Many of these controls are telecommunicationsbased. ${ }^{88}$ For example, restrictions on transborder data flow (TDF) 89 shape the geographic reach of the information system, as when TDE restrictions are severe, it is virtually impossible to link together an information system and thereby provide a consistent platform for a worldwide application. These restrictions can also have a severe influence upon in- 
ter-organization systems within the confines of the nation state. Legal requirements regarding trade documentation and liability, restrictions placed on networking by the telecommunications authorities, availability of specialized infrastructure, such as value-added networking, are all examples of factors which would tend to limit the geographic spread of the information system. If there are a great number of restrictions which tend to limit geographic reach, then the overall informatization of the society would be inhibited. Like the restrictions targeted against supply, state actions which tend to inhibit geographic reach may be aimed either directly at a policy oriented specifically towards information technology or may be a spin-off from concerns about other sectors of the economy. In either case, however, these restrictions tend to limit the development of higher-level sector-wide integration efforts.90 These three dimensions supply, range, and reach - are summarized in Table 1.

Table 1

DIMENSIONS OE NATION STATE CONTROL OVER INEORMATION TECHNOLOGY Proliferation and Applications Range Geographic Reach Supply

\begin{tabular}{|c|c|c|c|}
\hline $\begin{array}{l}\text { Defin- } \\
\text { ition }\end{array}$ & $\begin{array}{l}\text { Availability of } \\
\text { computer equipment } \\
\text { and telecommunica- } \\
\text { tions resources in } \\
\text { a national market }\end{array}$ & $\begin{array}{l}\text { Degree of integra- } \\
\text { tion between dif- } \\
\text { ferent functional } \\
\text { applications within } \\
\text { complex organiza- } \\
\text { tions }\end{array}$ & $\begin{array}{l}\text { Physical and spa- } \\
\text { tial spread of a } \\
\text { computer system, } \\
\text { including extent of } \\
\text { international or } \\
\text { inter-organiza- } \\
\text { tional linkages }\end{array}$ \\
\hline Examples & $\begin{array}{l}\text { Industrial policy } \\
\text { actions. } \\
\text { Taxes, tariffs and } \\
\text { NTBs against im- } \\
\text { ports. }\end{array}$ & $\begin{array}{l}\text { Use of administra- } \\
\text { tive controls to } \\
\text { throttle integra- } \\
\text { tion. Privacy reg- } \\
\text { ulations. } \\
\text { Inspection, licens- } \\
\text { ing, and taxation } \\
\text { of databases. }\end{array}$ & $\begin{array}{l}\text { Manipulation of } \\
\text { telecommunications } \\
\text { linkages, including } \\
\text { TDF regulations, } \\
\text { licensing of link- } \\
\text { ages, of discrimi- } \\
\text { nation against } \\
\text { VANs. }\end{array}$ \\
\hline
\end{tabular}

These three types of controls which are implemented by different nation states, when assessed in light of their complexity, experience great variation on a nation-to-nation basis. ${ }^{91}$ However, merely identifying that nation states have 
very different policies is not sufficient. What accounts for this variation? is the question which must be asked.

These controls are put into effect according to the individual goals and priorities which are expressed in national policy. These policies may be broad in their general intent, and their implementation, using the various levers of national control and influence, but they are first of all determined by the grand strategy of the state seeking to optimize its wealth and power. We see this by examining how nations in different economic circumstances have responded to the coming "information society."

\subsection{Linking National Goals and Information Technology Policies}

The first tier innovators are confident about much of their ability to withstand competition from imports of information technology, and have powerful interest groups which continually probe government circles to work harder at opening up foreign markets to access. These nations tend to promote a comparatively open regime.92 The second tier innovators, at least through the $1980 \mathrm{~s}$, have been involved in playing "catch up" in the technology race with the United States and Japan. They have subscribed to the relatively open trading regime of the GATT, but have at the same time taken actions to control the operations of foreign multinationals in their territories, and also have worked at adopting various national programs to build up their own domestic computer industries by encouraging local production and by controlling foreign direct investment in the information technology and telecommunications sectors. The East Asian NICs have worked hard at encouraging sub-contracting and manufacturing of increasingly higher value-added products. The East Europeans and Soviets have had a unique policy towards information technology caused in great part by their being boxed in by the COCOM program aimed at limiting technology transfer from West to East. Other countries either have no significant 
policy goals in this regard, or have weaker variations of these policies. However in each case - depending on the general economic level of the nation state, and on their relative position within the international system of innovation, manufacturing and utilization, all combined with their national goals - the way in which they control the supply, reach and range of information technology varies.

These variations are summarized in Table 2, which suggests a rough first approximation to the relationship between national goals and the use of the available policy levers.

Table 2

NATIONAL GOALS AND POLICIES TOWARDS INFORMATION TECHNOLOGY

\begin{tabular}{|c|c|c|}
\hline Type of Country & $\begin{array}{l}\text { Goal of Information } \\
\text { Technology Policy }\end{array}$ & $\begin{array}{l}\text { Implementation of Policy } \\
\text { through "Range", "Reach" and } \\
\text { "Supply" Policy Levers }\end{array}$ \\
\hline $\begin{array}{l}\text { Eirst Tier } \\
\text { Innovator }\end{array}$ & $\begin{array}{l}\text { Promote national } \\
\text { wealth. }\end{array}$ & $\begin{array}{l}\text { Promotion of open regime, } \\
\text { particularly for exporters. }\end{array}$ \\
\hline $\begin{array}{l}\text { Second Tier } \\
\text { Innovator }\end{array}$ & $\begin{array}{l}\text { Catch up with first } \\
\text { tier innovator. }\end{array}$ & $\begin{array}{l}\text { Limit activities of first } \\
\text { tier information technology } \\
\text { manufacturers. Encourage na- } \\
\text { tional industry. }\end{array}$ \\
\hline East Asian NICs & $\begin{array}{l}\text { High value added manu- } \\
\text { facturing and export- } \\
\text { led growth. }\end{array}$ & $\begin{array}{l}\text { Subsidies to national indus- } \\
\text { try and reserved market for } \\
\text { manufactured goods. Lax in- } \\
\text { tellectual property protec- } \\
\text { tion. }\end{array}$ \\
\hline $\begin{array}{l}\text { Middle Income } \\
\text { oil Exporter }\end{array}$ & No significant policy. & Open regime. \\
\hline $\begin{array}{l}\text { Middle Income } \\
\text { Dil Importer }\end{array}$ & No significant policy. & $\begin{array}{l}\text { Some limitations on supply, } \\
\text { but for foreign exchange } \\
\text { reasons. }\end{array}$ \\
\hline Asian Developing & $\begin{array}{l}\text { Catch up with East } \\
\text { Asian NICs. }\end{array}$ & $\begin{array}{l}\text { Subsidies to national indus- } \\
\text { try. }\end{array}$ \\
\hline $\begin{array}{l}\text { African } \\
\text { Developing }\end{array}$ & No significant policy. & $\begin{array}{l}\text { Controls over supply, but } \\
\text { for foreign exchange reasons } \\
\text { (not market protection). } \\
\text { Allow some MNCs to use. }\end{array}$ \\
\hline East Europeans & $\begin{array}{l}\text { Catch up with second } \\
\text { and first tier innova- } \\
\text { tors. Obtain access to } \\
\text { Western technology. }\end{array}$ & $\begin{array}{l}\text { Subsidies to state-owned na- } \\
\text { tional industries. } \\
\text { Encouragement of joint ven- } \\
\text { tures and importation of key } \\
\text { technologies. }\end{array}$ \\
\hline
\end{tabular}




\section{CONCLUSIONS}

These considerations, then, help to explain why we see wide differences in the texture of computing around the world. We briefly summarize as follows:

- There are vast differences in the use of information technology around the world caused by the economic disparities between countries, particularly between developed and developing countries.

- Although much in the international regime appears to help in the diffusion of information technology, nation states have reacted differently according to their levels of development and goals regarding information technology.

- The policy responses of the nation state have been exercised through different levers which influence. the range, reach and supply of information technology in individual countries.

We can now begin to suggest a tentative explanation for the high variability which exists in different parts of the world. We identified two levels of phenomena which need more explanation: the first level describes the differences in utilization between one country and another; the second level is oriented towards explaining the dynamics of transnational systems.

It appears that in terms of national differences much of the variation can be explained by the underlying economic differences between nation states. Where the country is 10cated on the developed-developing scale is probably the best indicator of its data processing landscape. This correlation helps to lay the groundwork for a first order explanation. When we examine the variations between different countries with roughly the same economic level of development, then variations in national culture play a greater explanatory role, particularly as concerns the data processing range. For example, much of the appropriate technology debate is oriented towards helping match the utilization of available 
technology in any given situation against the cultural attributes of the country into which it is being inserted.

It is more complex to explain transnational computing systems because there are many more factors involved. First of all, it appears that many multinational corporations have developed geographically dispersed systems, even when centrally coordinated systems might be economically better in the absence of any nation state-imposed restrictions on data processing. Some centralized systems which, from an operational point of view, can work best only with a single point of command, are prohibited from operating in that manner because of nation state-imposed controls and regulations. The underlying purpose of the transnational system might be in conflict with the nation state and may suffer. As a result of all these variations, we can see that the natural balance between centralization and decentralization has been upset by the nation state in its haste to both develop and optimize its individual position vis-a-vis the entire world system. Another important observation is that there are virtually no known measurements of these effects and a great deal of effort must be made in this direction in order to understand in greater depth the dynamics of global computing.

Einally, the general rise of transnational systems made possible by the liberal international regime put in place after the Second World War has not stopped, and there is no indication of any decline in the near future.

\section{AN AGENDA FOR FURTHER RESEARCH}

Research in the future should focus on several key areas of inquiry including understanding the global proliferation of information technology; intensifying the effort to understand the social and cultural effects of information systems particularly in non-Western countries and cultures; and assessing the broader effects of the rise of transnational information systems. In addition, a 
reassessment must be made of the role of international organizations in managing the rise of transnational information systems.

\subsection{Proliferation of Information Technology and Emerging Industrial Structures}

Although much of the genesis of today's information technology was confined to a few geographic areas, and could thus be studied by examining the progress of a handful of key countries, the situation has changed rapidly, with the domination of a few being replaced by the chaos of new entrants. This has fostered the creation of a noncentralized pattern of activity on a world scale, and made it considerably more difficult to understand trends.

A particularly important development taking place at the end of this millineum is the dismemberment of the socialist empire of the Soviet Union and Eastern Europe and its replacement with a system of more autonomous nation states. The implications for the computer industry are hard to estimate, as the large manufacturing and $R \& D$ system built up in CMEA must now be restructured and integrated into the world wide system of computer development and application, but such integration will come in parts and not as a whole, since the "unified system of computers" is no longer with us. The rapid injection of this vast prospective market and pool of talent into the worldwide system will generate many effects which call for analysis.

More generally, understanding the emerging global structure will be a major task of research and will require enormous effort and many skilis and methodologies, including multilingualism, sophisticated modeling, many case studies, and very wide bandwidth environmental scanning capabilities. There are more than 100 countries in the world and we can expect many different reactions to this new structure and the pressures it will bring to bear. 


\subsection{Social and Cultural Effects of Computerization}

The broadest and perhaps most unfathomable area of inquiry in the future will rest upon the modest amount of research done in the past examining the social and cultural effects of computerization. The concerns expressed thus far regarding "electronic colonialism" may have seemed controversial at the time they were made, but they were a small noise compared to what may be heard in the coming decades as the "information revolution" makes itself felt in the vast uncharted waters of the developing world. We genuinely wonder whether ancient cultures will survive this onslaught of information technology, and how adjustments will be made as this technology sweeps through the world and eats through layer after layer of custom and facade.

Within the developed world, the study of social and cultural effects, including the tired debate regarding how computerization changes organizations, will continue to draw attention, but new requirements of this research will continue to arise as its global and transnational nature strengthens. Will we see a standardization of architectures and technological approaches to informatization which will provide global efficiency but at the expense of crushing diversity and perhaps creating a new class of information system tsars? How will different societies adjust and what will be the effects on national sovereignty? How will advanced economies regulate information-based economic transactions, such as trade in services, when the location of the transaction is not clear due to the global complexity of the information system on which it is being hosted? What will be the prospects for industrial policies aimed at mastering the new generations of information technology? Within the context of global and transnational information systems, how long will it remain important to continue to treat the nation state itself as the key unit of analysis? And if not the nation state, then what are the new units of 
analysis which must be employed in order to understand these emerging systems?

The tools in this future stream of research will be highly varied, and we doubt any one approach or methodology will gain a monopoly. The study of the social, political and cultural effects of global proliferation of computing technology should produce a new renaissance in scholarly research as disciplines as diverse as political science, sociology, linguistics, international law, anthropology and economics are co-opted into the study of international information technology issues. This will happen precisely because it should challenge and break down the ivory castles of rigid disciplines which have been carefully constructed in the West in a small number of universities and in a closed circle of acquaintences and journals. We need to see if other peoples have anything fundamentally different to say.

\subsection{System Dynamics of Transnational Information Systems}

Another important line of research will examine the growth and dynamics of large international computer and communications systems as phenonema in themselves. What are their properties? How do they grow? What are their underlying characteristics and families of variation? What are the most important environmental factors which influence how they are designed and how do these factors operate? For example, what are the factors causing global systems to develop in a centralized fashion or in a decentralized fashion? What are the precise causal mechanisms involved and how can they be quantified, modeled, and generalized into a significant theory?

These and other questions beg answering as we approach a new era of technology in which computers will be linked together on an international basis as needed into virtual ad hoc arrangements which will be brought into being to service specific time delimited purposes then disbanded shortly 
thereafter. The dynamics of such systems will be considerably different from the "old" rigid arrangements oriented towards building stable, predominately hierarchical, systems around specific purposes. These radical new architectures will give final life to the "networked society" and "global village" which has been written about and speculated about for so long. In addition, they will tremendously obfuscate the true nature of the systems themselves because it will be considerably more difficult to study these moving targets. As a result attention will of necessity be placed on theoretical navigation of the exploding electronic information space in the broadest meaning of the term, as its proliferation and growth increasingly absorb the paper-based bureaucracies and control systems so loved and used in society since before the time of Augustus and Justinian. In the design and implementation of these systems, a great deal of human cleverness and intuition will be needed to balance between the forces of regimentation, logic and automaticity as opposed to the flexible, sometimes chaotic and impulsive nature of human society; and as these massive and complex channels of information processing are built and refined, a wide canvas will be painted with the many irreconcilable conflicts of different cultural civilizations. Indeed, the study of this new phenomena will be a rich area of inquiry, and the researcher will have to take on baggage from many disciplines in order to sense the full flavor of the change.

\subsection{The Role of International Organization and Law}

The last half century has seen the rise of new technologies including telecommunications of all types and information technology which have generated an effective shrinkage of the world system. The fall of the Berlin wall, the rise of instant global television, the development of long range commercial aircraft, and the refinement of the 
world's telephone and data communications systems have heightened the concept of the world as a single political and economic system.

Within the context of information technology, then, we can see the increase in problems which can be handled only at the international level, away from the exclusive control of single nation states. Protection of intellectual property rights, creation of the massive information technology infrastructure which will continue to build the fabric of a global information society, allocation of investments to the developing world, creation of educational programs which will build the engineers and thinkers of the following generations are all examples of areas where international organizations will play a critical role. But we are not sure that international organizations as they are working today are sufficiently organized to handle the challenges of the future, if we judge from the contradictory and un-coordinated record of the past. In the coming decades, they must be able to handle massive world-spanning projects, and yet remain sensitive to the local needs of individual nation states, and to cultures and ways of life which are endangered.

As a result, much research needs to address the problems of international organization and the underlying structures of political economy and law which will shape the applications of information technology in the next millineum. How priorities are set, decision making rules for resource allocation, how opposing or multiple interests are balanced against one another, how global inequalities, including the persistent crisis of "information poverty," are to be addressed, how different practices and standards are to be reconciled, and generally how information technology can be better integrated into the world's cultural and economic system are the questions destined to drive research. 
12. NOTES

t We would like to thank the following people for their comments on previous drafts of this paper: Michael Blaine, Kenneth C. Laudon, Tom Jarmoszko and Peter Wolcott. We also wish to thank Renata de la Rovere for her comments on modernization of the Brazilian computer industry, Joey George for his help and discussion in finding key references concerning the information society, and Gene Mesher for help with the research on dependency and innovation theory. The administrative assistance of Annette Mehrer is much appreciated. We should also like to thank the many students who helped in the library research.

'At an educational institution visited, one of the directors, who helped bring the machine into Romania in the late $1960 \mathrm{~s}$, was purged under Stalinist Ceaucescu and has now been rehabilitated. He is now trying to revive the curriculum to help build a market economy. See Goodman (1991).

${ }^{2}$ All of the examples here are gathered from interviews.

${ }^{3}$ See Rogers and Larsen (1984).

"See Hofheinz and Calder (1982) who use the term "Eastasia" to represent the Confucian societies of Asia, except for mainland China, which is still dominated at least superficially by the imported Western culture of Marxism-Leninism.

SThese are occasionally abbreviated NICs for "Newly Industrializing Countries". ${ }^{6}$ For a discussion of Taiwan see Lee (1990): Mr. K. D. Lee (advisor of the President, often considered as the father of Taiwan IT industry) remarked: "Technology and application research and development should be the focus of Taiwan IT in the next decade. We should use marketing information systems to identify market needs and product opportunities. We should focus on creative and high value-added information products in the 1990 s."

'See Jonasson, Elling and Yngström (1985).

${ }^{8}$ See Berleur, Clement, Sizer, and Whitehouse (1990) for a collection of essays touching upon many of the social aspects of computing, including power relationships, organizational changes, patterns of thought, and other factors. There are few references to the international dimension, but the phenomena discussed can be analyzed from one society to another on a comparative basis.

9The term "Silicon Utopianism" might be associated with such writers as Deken (1982). Gassée (1985), Evans (1979), Gilder (1989), Louv (1983), Martin (1981). See Masuda (1985 and 1988) for a Japanese version.

${ }^{10}$ See Nilles (1984), and Vallee (1982).

11 See Keohane and Ooms (1972) for key definitions of transnationalism.

12 This refers to the utilization and application level, not to basic engineering and manufacturing of computer products.

${ }^{13}$ See Roche $(1991 \mathrm{c})$.

${ }^{14}$ With the current failings in the GATT, there is talk in the early 1990 s of reviving the ITO in perhaps a new form, with a new name (to distinguish it from ITO) of World Trade Organization. (NB: Not to be confused with the international marketing arm of IBM, also called the World Trade Organization.) The Truman administration killed the effort to get the ITO charter ratified by the U.S. Senate when private sector complaints became too loud to ignore. The definitive study of this is found in Diebold (1952).

${ }^{15}$ For the historical perspective, see Nussbaum (1947).

${ }^{16}$ The structure of this system and its constituent parts are discussed in United Nations (1979). See also Sohn (1967).

${ }_{17}$ For example, the international trading regime is a system in which nation states voluntarily limit their actions in controlling international trade because they are convinced that if every nation state does the same, the total amount of wealth generated around the world will be greater. This principle of trading off individual benefits against group benefits is the key of the matter, and yet it is rare that nation states voluntarily enter into international arrangements in which they yield benefits and get fewer in return. With more than 100 nations involved, it should be no surprise that international negotiations on multilateral organizations take quite a long time. See Henkin (1979) for a discussion of how nations conduct their foreign policy within the context of international law. 
${ }^{1 \theta_{A}}$ partial list of the international organizations include: Internatinal Atomic En-
ergy Agency, International Labour Organisation, Food and Agriculture Organization of
the United Nations, United Nations Educational, Scientific and Cultural Organization,
World Health Organization, The World Bank, International Monetary Fund, International
Civil Aviation Organization, Universal Postal Union, International Telecommunications
Union, World Meteorological Organization, Inter-governmental Maritime Consultative organization, World Intellectual Property Organization, International Fund for Agricultural Development, and the General Agreement on Tariffs and Trade (GATT). 19 These are a representative sample of the most important international organizations which have an influence upon the development of international computing, although to a greater or lesser extent all international organizations have at least some influence. ${ }^{20}$ To view how the different legal systems in the world interact, see David and Brierly (1968).

${ }^{21}$ For a brief history see Roche (1991b) pp. 3-15, and Roche (1980).

22 This is done through the International Frequency Registration Board (IFRB) which maintains the Master International Erequency Register and keeps it up to date.

${ }^{23} \mathrm{By}$ the end of the 1980s, an investigation by the Financial Times discovered that users were being over-charged for international telephone communications by more than 11 billion dollars per year. This is because the different PTT's around the world cooperated with each other to keep prices for international traffic up in order to subsidize domestic telecommunications charges.

${ }^{24}$ For an example of the complex web of activities and issues see ITU (1985).

${ }^{25}$ For a discussion of the political dimension of international standards, and how they interact with industrial policy, see Crane (1979), who studies color television as a case study.

${ }^{26}$ See IEEE (1989).

${ }^{27}$ The World Intellectual Property Organization (WIPO), headquartered in Geneva, was created as the $14 \mathrm{th}$ specialized agency of the United Nations by a treaty in 1967 . It is the descendant of the 1883 Paris Convention and the 1886 Bern convention which created the International Union for the protection of Industrial property and the International Union for the Protection of Literary and Artistic World which had been combined in 1893 under the name United International Bureaux for the Protection of Intellectual Property (BIRPI).

The WIPO operates to protect both patents and copyrights, in other words both industrial property and intellectual of artistic property. It has struggled with the protection of software, including software which has been embedded into ROMs (which has the qualities of both industrial property and literary work at the same time). Although the debates over protection of intellectual property in high technology have been long, the international community has been steadily moving towards recognition of the importance of the issue. The United States has led the way in this effort and to a certain degree has been supported by Japan.

The intellectual property protection of software has gone far in helping promote the continued development of international computing. As the regime of intellectual property protection is solidified, vendors will find it easier and more profitable to expand their activities into different countries, rather than only into the most developed countries. This process is another accelerator of global diffusion, and it has helped a great deal in the spread of the contract programming industry into developing countries such as India, Mexico and Ireland. However, the effect of WIPO has been considerably less than that of the ITU.

${ }^{28}$ It is also very much a developing area of domestic law, which itself is not wellformed, although improving. For an introduction to this field, overlapping as it does law, economics, and competition between firms, see National Research Council (1991).

${ }^{29}$ Intergovernmental organizations are distinct from international organizations. They are formed by voluntary agreement between nations, but not specificially through a process of multilateral treaties as is the case with international organizations. During its life, the IBI and its tireless secretary general Fermin Bernasconi were constantly searching for new memberships of different governments. The United States was always in the process of declining because it didn't wish to be hit with obligations for donations. The U.S. continued to send observers to various IBI meetings, and there was a significant amount of informal participation on the part of many Americans. When the IBI attempted to hold a large world informatics conference in Havana Cuba, it signaled the eventual end of the organization and the complete drying up of any growing U.S. support. 
${ }^{30}$ The Group of 77 was composed of activist developing countries which tended to vote in a bloc in various international fora.

${ }^{31}$ The IBI eventually collapsed in an international scandal involving theft of gold medals in the mid-1980s.

${ }^{32}$ See Pipe and Veenhuis (1976).

${ }^{33}$ The term informatics refers to information and telecommunication technologies used together. The French term is either telematique or informatique.

3'One experiment, for example, attempted to use VSATs (Very Small Aperature Terminals) for remote data telecommunications from remote hospitals in developing countries in Africa. See Roche (1991b) pp. 117-129.

35 See Schiller $(1973,1981$ and 1984$)$.

${ }^{36}$ The term development theory refers to the body of knowledge and literature which is concerned with how nations as a whole develop their economies, and in particular identification of the most effective policies which might be adopted by international development agencies or international organizations aimed at promoting better economic progress in the Third World.

${ }^{37}$ For a discission of World Bank activities, see Saunders, Warford and Wellenius (1983) and for a more general discussion see Saunders (1982). Software manufacturing strategies for developing countries is covered by Schware (1989).

${ }^{3}$ This is discused by Azikiwe (1965). Emerson and Kilson (1965), Mazrui (1973), Nursey-Bray (1973), Singham (1977), and Stavrianos (1981). See also Nkrumah (1963).

${ }^{39}$ The concept of unequal production has its origin in writers such as Sweezy (1942), de Silva (1982), Frank (1960, 1978 and 1979), Baran (1957), Amin (1973 and 1974). See also Wallerstein $(1976$ and 1980). For more details on Africa, see Arrighi and Saul (1973) as well as Makgetla and Seidman (1980).

${ }^{40}$ See Kaplinsky (1985) for an analysis of how information technology can be used in developing countries for improving manufacturing. He argues that "synergestic technologies (intra-sphere or inter-sphere automation)" are necessary, otherwise the developing world will not be able to "arrest the likely trend towards comparative advantage reversal".

${ }^{41}$ One picture which comes to mind is the giant overpass intersection in the middle of a remote location with no completed roads connecting it and with bands of nomads living underneath the shelters. Fortunately this has not yet been seen with data highways.

${ }^{42}$ See Bernasconi (1985) as well as Bernasconi, Piera, and Soupizet (1986).

${ }^{43}$ Schiller's pioneering work took a great deal of dependency theory and re-wrote it in terms of information technology. More comprehensive references which examine a Marxist or Neo-Marxist perspective are found in de la Haye (1979) and International General (1978).

${ }^{44}$ This was most famous in Africa, where from a former French colony a long distance telephone call would be routed through Paris then London back to the capital of the adjoining African state which itself was a former colony of England.

${ }^{45}$ The Turn model was reproduced widely and used in such authoritative publications as the UNCTC report on Transborder Data Elows and Brazil, done in 1986. See UNCTC (1983).

${ }^{46}$ This phrase is from Roche $(1981 / 2)$.

${ }^{47}$ Eor a view of information technology used for enslavement, see Pirow (1985).

${ }^{48}$ For details of how this is done with semiconductors see McIvor (1989); for analysis of other components see Anderla and Dunning (1987).

${ }^{49}$ Renata La Rovere provided a great deal of insight on this particular aspect of the Brazilian situation. See Lebre La Rovere (1990).

${ }^{50}$ For a discussion regarding national industrial policies towards the information technology sector and its relationship to the size of the national market, see Roche (1991a).

${ }^{51}$ Mexico perhaps has a large enough internal market to support some manufacturing of small-scale information technology, and tried an autonomous strategy for approximatley one-half of a century, but has not opted for the free market approach implied in the current negotiations with the U.S. over a free trade agreement.

${ }^{52}$ We know now that there are ways to cope with this problem by designing and implementing different human interfaces to a relational database - interfaces which might be customized, user-oriented, etc. However, when this debate took place in the mid-1970's, this approach to the user interface was not a widely shared concept. Newer concepts of "intelligent" database retrieval systems are found in Chen (1991). 
${ }^{53}$ There is a vast literature on France. See Lasfargue (1987), Rigal (1985), Bertini
and Richard (1985). Marchand (1987) as well as the well-publicized report by Nora an Mine $(1981)$.

${ }^{54}$ See Mattelart (1983).

${ }^{55}$ Schware and Trembour (1985) review the expanding use of microcomputers in the Third World and emphasize that unless data is already organized on a manul basis before computerization is introduced, there is likely to be chaos. They also make observations regarding some cultural factors. See also National Research Council (1988).

56UNESCO has developed such programs as the Experimental World Literacy Programme, the International Hydrological Decade, the Man and the Biosphere program, and many other broad and universal programs intended to benefit all of humanity.

${ }^{57}$ It was argued, for example, that the western news media tended to report only natural disasters, military coups, or other negative events in developing countries, and had displayed almost no cultural sensitivity towards the people of color of the world. 58political agenda formation in international organizations is determined in great part. by the type of voting system used for decision making. The General Assembly, the ITU, UNESCO, and the IBI are all set up on a one-nation one-vote basis. In these organizations, the voice of the developing countries became very strong as the immediate post war wave of decolonialization took hold, the result being a type of radicalization of these international organizations. On the other hand, the Security Council has a veto power of the Permanent Members, and the World Bank works by a system of quotas roughly proportional to the economic power of the member countries. 59 This is not as straightforward as it seems. When there are no national restrictions, multinational corporations in many cases have no incentive to invest overseas, in which case there might be an even smaller transfer of information technology into other countries. It appears that restrictions against free trade might great ly facilitate technology transfer, but this specific problem has not been studied as far as we know

${ }^{60}$ The International Monetary Fund, the ITO and the GATT, the International Labor Organization (ILO), and the World Bank all together make up the principal

international economic organizations which were organized with the United Nations following the Second World War.

${ }^{61}$ The World Bank classifies countries into several groups. G-7 includes the United States, Japan, Germany, France, United Kingdon, Italy and Canada; developing countries are broken down into regions: sub-saharan Africa, East Asia, South Asia, Europe/Middle East/North Africa, and Latin America/Caribbean. The socialist countries are not included because they are not members of the International Monetary Eund. See World Bank (1988).

${ }^{62}$ For a study of software see Schware (1989).

63 See Saunders, Warford and Wellenius (1983).

${ }^{64}$ However, even as late as 1989 , telecommunications development accounted for only seven projects and less than $3 \%$ of the development funding from the Bank, although more than $90 \%$ of all development projects had at least some type of information technology component with about 50 s of those components being in either finance and accounting or management information systems applications. See World Bank (1990). ${ }^{65}$ See Hanna (1991) for a sweeping analysis of the many factors involved for the developing world as it moves into the $1990 \mathrm{~s}$.

${ }^{66}$ This began immediately after the wave of decolonialization which had come in the $1950 \mathrm{~s}$ and $1960 \mathrm{~s}$. As a result, it greatly increased the number of voting members of the United Nations.

${ }^{67}$ Cuban foreign policy seems almost totally oriented towards being obstructionist to any international efforts supported by the United States. This will probably continue until Castro passes from the scene. Many of the arguments posed by cuba in the international debates on the New World Information Order displayed an ignorance of technololgy. For example, Cuba had long passionate arguments supporting allocation of parking spaces for satellites based on premises which ignored advances in statistical and time-division multiplexing.

68 See Melody (1984).

${ }^{69}$ For discussion of international trade in services, see Feketekuty (1988), also Aronson and Cowhey (1988).

${ }^{70}$ See Noam (1989). 
7isee Mathew (1985), McAnany (1980), Williams (1976). Schware and Choudhury (1988) review the role of different international aid agencies and conclude that "few of these organizations see information technology as a new and important sector in development". They note that on average, for the World Bank, the "cost of IT as a percentage of total project cost is usually very small, less than five percent." 72 To imagine how desperate the situation is, we can refer to schware (1989) who discusses how poor countries can use public domain software (i.e. software with no comnercial value) in attempting to improve their information processing capabilities. ${ }^{73}$ For a discussion of the economic basis of these classifications, see World Bank (1988). We have modified the categories somewhat to take into consideration innovation.

74 These are labled "Asian Developing" by the World Bank, but we had to separate out the NICs from other "Asian Developing" countries, because of their special role in the international computer industry. NICs include Korea, Taiwan, Singapore, and to a lesser extent Thailand and the Philippines.

75 For example, see Institute for Information Industry (1989).

76 See National Research Council (1990) for a discussion of the prospects of information technology development in Africa. The panel report focuses on the need for strenghtening the availability of scientific and technical information throughout the developing countries of Africa and is very optimistic regarding the use of DC-ROM technology for delivery of information.

77 In the case of Taiwan, some data is available. See Institute for Information Industry (1990), p. 37: "Annul export contribution of foreign-invested firms in $1984,1985,1986,1987$, and 1988 was: $57 \%, 58 \%, 44 \%, 39 \%$, and $37 \%$, respectively. The percentage of OEM purchase was $408,37 \%, 398,418$, and 418 , between 1984 and 1988 . The dominating status of foreign-invested firms declined. While these firms still occupied 10-15 seats of the top 30 information product companies, their export contribution dwindled to $37 \%$, from 608 in 1984 . The U.S. was still the largest overseas market, but the importance of the European market began to rise."

${ }^{78}$ See Davis and Goodman (1978) and Goodman (1985).

79 Much of manufacturing in Brazil is done through licensing, and in addition, IBM's role as a major "Brazilian" manufacturer also fits the dependent manufacturing mode. So Brazil has some of the characteristics of both autonomous and dependent manufacturing. Cline (1987) is negative towards the Brazilian type of policy. He noted that "policy in the informatics sector closely parallels national development strategies" and that Brazil's adoption of import substitution was in keeping with what it has done in other sectors. His analysis led him to conclude "skepticism about the advisability of high protection for the informatics sector on infant industry grounds" citing "creating inefficient industries" as being one of the principal problems encountered with this strategy.

${ }^{80}$ For discussion of the Taiwan case see Wang (1990), pp. 8-9. "The Business Software Association (BSA), formed by major U.S. software firms including Apple, Lotus, and Microsoft, sent representatives to Taiwan in April, 1990 to investigate the violation of software copyright. BSA also intended to crack down illegal software uses in the central and southern regions of Taiwan. This series of actions revealed the software piracy practices that have been tolerated in the public and private organizations despite the government's stated intention to support the Copyright law."

81 This is similar to other industries such as chemicals, biotechnology, and even automobiles, but to a lesser extent.

${ }^{82}$ For example, see the Taiwan case in Institute for Information Industry (1989), P. 9. "Assisting local manufacturers to get loans has been an important element of the government's promotion of the strategic industries in the ROC. Those manufacturers engaging in strategic industries are entitled to apply for loans from both the Bank of Communications (BOC) and the Taiwan Medium Business Bank (TMBB). As of the end of 1988 , the BOC approved 41 cases, for loans totaling NTS 2.1 billion (about US\$ 70 milition), and the TMBB approved 25 cases, for NTS 130 milition (about USS 4.5 million). The Ministry of Economic Affairs also implemented the "Encouragement of New Industrial Products Developed by Private Enterprises" in 1984, providing subsidy to private enterprises. By the end of June 1988, the government approved 22 cases, with a total of NTS 509.595 million (about US\$ 17 million).

${ }^{83}$ See United States Trade Representative (1982). There are a vast number of controls, but we do not intend to go into them in great detail in this paper. For details, the 
reader should consult first the USTR report and then for an analysis of Japan see Anchordoguy (1989).

${ }^{84}$ We realize, of course, that these generalizations are being applied to all 138 or so countries, and that there is a vast difference between the conditions in each. However, we believe these categories are fundamentally sufficient to be applied in each case, although they do suffer from being a type of generalization.

${ }^{85}$ For a discussion of Chinese policy and technology, see for example, Maier (1988), Baum (1986), Yun (1989), and Simon (1988 and 1989).

"Keen makes a distinction between "range" and "reach" in the information system. He describes geographic reach as being equivalent to the physical distances linked together within the MNC's information system. See pp. 39-40 of Keen (1991). The same concept is discussed in IBM Corporation (1990). However, the IBM definitions are slightly different and may appear broader in that they include inter-organizational systems.

${ }^{87}$ For example, an incoming order into the sales department may automatically trigger actions on the manufacturing line, if the applications range within the firm is great. ${ }^{88}$ See Hoffman and Clark (1990) for a discussion of policy problems with building national and international computer networks. They emphasize concerns regarding privacy, security, and access issues. This stream of thought has its genesis in the long-standing debate regarding privacy and computerization. See Westin and Baker (1972).

${ }^{89}$ Transborder data flow is occasionally abbreviated TBDE.

${ }^{90}$ In Japan, for example, government policy has been encouraging expansion of reach in information systems through creation of national broadband ISDN systems combined with sector-specific policies, such as banking automation, retail sales automation, etc. 91 There is no available study which has done this, however.

${ }^{92}$ In recent years Japan has been a great promoter of free trade in information technology, particularly for its exports, although its policies in the past were highly protectionist. As Japan gained power in one electronic sector after another, it tended to change from protectionism to "free trade." It is true, for example, that semiconductor manufacturers are welcome to go into the Japanese market to compete against NEC, Toshiba, Hitachi, and other Japanese giants, but these companies now have the advantage of the innovator. 


\section{REFERENCES}

Amin, S. (1973). "Neo-Colonialism in West Africa." Monthly Review Press, New York and London.

Amin, S. (1974). "Accumulation on a World Scale: A Critique of the Theory of Underdevelopment." Monthly Review Press, New York and London.

Anchordoguy, M. (1989) . "Computer Inc: Japan's Challenge to IBM." Harvard East Asian Monographs, 144, Harvard University Press.

Anderla, G. and A. Dunning (1987). "Computer Strategies 1990-9: Technologies - Costs - Markets." John Wiley \& Sons, Chichester, New York.

Aronson, J.D. and P.E. Cowhey (1988). "When Countries Talk: International Trade in Telecommications Services." Ballinger Publishing Company, Cambridge, Massachusetts.

Arrighi, G. and J.S. Saul (1973). "Essays on the Political Economy of Africa." Monthly Review Press, New York and London.

Azikiwe, N. (1965). Pan-Africanism. In "The Political Awakening of Africa" (Emerson, R. and M. Kilson, eds.) Prentice-Hall, Inc., Englewood Cliffs, N.J.

Baran, P.A. (1957). "The Political Economy of Growth." Monthly Review Press, New York and London.

Baum, R. (1986). Dos ex Machina: The Microelectronic Ghost in China's Modernization Machine. Department of Political Science, University of California at Los Angeles.

Berleur, J., A. Clement, R. Sizer, and D. Whitehouse (1990). "The Information Society: Evolving Landscapes." Springer-Verlag, Captus University Publications.

Bernasconi, E.A. (1985). Information for Informatics, Informatics for Information. Agora (2), pp. 34-35.

Bernasconi, E.A., F. Piera and J.F. Soupizet (1986). A Meeting with IBI. Agora (2), pp. 1-15.

Bertini, M.T., and P.J. Richard (1985). " $L$ ' Informatique oui ou Non." Flammarion, Erance.

Chen, H. (1991). Cognitive Process as a Basis for Intelligent Retrieval Systems Design. Information Processing and Management. 27 (4).

Cline, W.R. (1987). "Informatics and Development: Trade and Industrial Policy in Argentina, Brazil, and Mexico." Economics International, Inc, Washington, D.C.

Crane, R.J. (1979). "The Politics of International Standards: France and the Color TV War." ABLEX Publishing Corporation, Norwood, New Jersey.

David, R. and E.C. Brierly (1968). "Major Legal Systems of the World Today." The Eree Press, New York.

Davis, N.C. and S.E. Goodman (1978). The Soviet Bloc's Unified System of Computers. ACM Computing Surveys 10 (2), p. 111.

de la Haye, Y., Editor (1979). "Marx \& Engels on the Means of Communication (The Movement of Commodities, People, Information \& Capital)." International General, New York.

de Silva, S.B.D. (1982). "The Political Economy of Underdevelopment" Routledge \& Kegan Paul plc., London.

Deken, J. (1982). "The Electronic Cottage." William Morrow and Company, Inc., New York.

Diebold, w. Jr. (1952). The End of the ITO. Princeton Essays in International Einance (16). 
Emerson, R., and M. Kilson, Editors (1965). "The Political Awakening of Africa." Prentice-Hall, Inc. Englewood Cliffs, New Jersey.

Evans, C. (1979). "The Micro Millennium." The Viking Press, New York.

Feketekuty, G. (1988). "International Trade in Services: An Overview and Blueprint for Negotiations." Ballinger Publishing Company, Cambridge, Massachusetts.

Erank, A.G. (1960). "Capitalism and Underdevelopment in Latin America: Historical Studies of Chile and Brazil." Monthly Review Press, New York and London.

Erank, A.G. (1978). "World Accumulation, 1492-1789." Monthly Review Press, New York and London.

Frank, A.G. (1979) . "Dependent Accumulation and Underdevelopment." Monthly Review Press, New York and London.

Gassee, J.L. (1985). "The Third Apple: Personal Computers and The Cultural Revolution." Harcourt Brace Jovanovich, San Diego, New York, London.

Geipel, G., A.T. Jarmoszko, and S.E. Goodman (1991). The Information Technologies and East European Societies. East European Politics and societies, forthcoming.

Gilder, G. (1989). "Microcosm: The Quantum Revolution in Economics and Technology." Simon and Schuster, New York.

Goodman, S.E. (1985). Technology Transfer and the Development of the Soviet Computer Industry. In, "Trade, Technology and SovietAmerican Relations" (B. Parrott, ed.), pp. 117-140. Indiana University Press, Bloomington.

Goodman, S.E. (1991). From Under the Rubble: Computing and the Resuscitation of Romania. Communications of the ACM, forthcoming.

Hanna, N.K. (1991). The Information Technology Revolution and Economic Development. World Bank Discussion Papers, No. 120.

Henkin, L. (1979). "How Nations Behave: Law and Foreign Policy." Columbia University Press, New York.

Hoffman, L.J. and P.C. Clark (1991). "Policy Considerations in the Design and Management of National and International Computer Networks." Department of Electrical Engineering and Computer Science, The George Washington University.

Hofheinz, R. Jr., K.E. Calder (1982). "The Eastasia Edge." Basic Books, Inc., New York.

IBM Corporation (1990). IBM Announces System/390. Videotape, September 5,1990 .

Institute for Information Industry, Taiwan (1989). Information Industry Handbook, Taiwan, ROC.

Institute for Information Industry, Taiwan (1990). Information Industry Handbook, Taiwan, ROC.

Institute of Electrical and Electronics Engineers (IEEE) (I989). "A Guide to Standards Development." IEEE, New York.

International General (IG) (1978). "Marxism and the Mass Media." Series No. 1-7, International Mass Media Research Center, Bagnolet, France.

International Telecommunication Union (ITU) (1985). "World Communications Forum." Speakers' Papers, Geneva.

Jonasson, S., M. Elling and L. Yngström (1985). Computers and the Swedish Society: A Report. In "Comparative Worldwide National Computer Policies" Proceedings of the Third IFIP TC9 Conference on Human Choice and Computers. (H. Sackman, ed.) North-Holland, Amsterdam.

Kaplinshy, R. (1985) Electronics-based Automation Technologies and the onset of Systemofacture: Implications for Third World Industrialization. World Development 13 (3), pp. 423-439. 
Keen, P.G.W. (1991). "Shaping the Future." Harvard Business School Press.

Keohane, R.O. and V.D. Ooms (1972). The Multinational Enterprise and World Political Economy. International Organization 26 (1), pp. $84-120$.

Lasfargue, Y. (1987). "Travailler Dans L'Informatique: 'reves et possibilites'." APEC, Paris.

Lebre La Rovere, R. (1990). Trajectoires de Modernisation Industrielle: une Approche Sectorielle. Ph.D. Dissertation, Universite de Paris.

Lee, K.D. (1990). Taiwan Information Industry: Strategic Directions for the Next Decade. Information and Computer (114).

Louv, R. (1983). "America II." Jeremy P. Tarcher, Inc., Los Angeles.

Maier, J.H. (1988). Thirty Years of Computer Science Developments in the People's Republic of China: 1956-1985. Annals of the History of Computing (10), 19-34.

Makgetla, N. and A. Seidman (1980). "Outposts of Monopoly Capitalism: Southern Africa in the Changing Global Economy." Lawrence Hill \& Company, Westport Connecticut.

Marchand, M. (1987). "Les Paradis Informationnels: Du Minitel Aux Services de Communication du Futur." Masson et CNET-ENST, Paris.

Martin, J. (1981). "Telematic Society: A Challenge for Tomorrow." Prentice-Hall, Inc., Englewood Cliffs, New Jersey.

Masuda, Y. (1985). Computopia. Agora (11), 40-41.

Masuda, Y. (1988). "The Information Society as Post-Industrial Society." Institute for the Information Society, Tokyo.

Mathew, R.M. (1985). Data Policies for Developing Countries. Agora (2), $4-12$.

Mattelart, A. (1983). "Transnationals and the Third World: The Struggle for Culture." Bergin \& Garvey, Inc., South Hadley, Massachusetts.

Mazrui, A.A. (1973). African Diplomatic Thought and Supra-nationality. In "Africa in World Affairs: The Next Thirty Years" (A.A. Mazrui and H.H. Patel, eds.) pp. 121-134. The Third Press, Joseph Okpaku Publishing Company Inc., New York.

McAnany, E.G., Editor (1980). "Communications in the Rural Third World: The Role of Information in Development." Praeger, New York.

McIvor, R. (1989). "Managing for Profit in the Semiconductor Industry." Prentice Hall, Englewood Cliffs, New Jersey.

Melody, W.H. (1984). The Radio Spectrum: Principles for International Policy. In "World Communications: A Handbook" (G. Gerbner and M. Siefert, eds.) Longman, New York \& London.

National Research Council (1988). Cutting Edge Technologies and Microcomputer Applications for Developing Countries. Board on Science and Technology for International Development, Westview special studies in science, technology, and public policy, Boulder, Colorado.

National Research Council (1990). "Science and Technology Information Services and Systems in Africa." National Academy Press, Washington, D.C.

National Research Council (1991). "Intellectual Property Issues in Software." Steering Committee for Intellectual Property Issues in Software, National Academy Press, Washington, D.C.

Nilles, J. (1984). Managing Teleworking. Prospectus for a Study, Center for Eutures Research, Graduate School of Business Administration, University of Southern California at Los Angeles (mimeo).

Nkrumah, K. (1963). "Africa Must Unite." International Publishers, New York.

Noam, E. (1989). International Telecommunications in Transition. In "Changing the Rules: Technological Change, International 
Competition, and Regulation in Communications" (R.W. Crandall and K. Elamm, eds.) pp. 257-297. The Brookings Institution, Washington, D.C.

Nora, S. and A. Minc (1981). "The Computerization of Society." MIT Press, Cambridge.

Nursey-Bray, P.F. (1973). The Polis, the African Traditional Community, and African Natural Law. In "Africa in World Affairs: The Next Thirty Years" (A.A. Mazrui and H.H. Patel, eds.) pp. 23-36. The Third Press. Joseph Okpaku Publishing Company Inc., New York.

Nussbaum. A. (1947). "A Concise History of the Law of Nations." The Macmillan Company, New York.

Pipe, G.R., and A.A.M. Veenhuis, Editors (1976). National Planning for Informatics in Developing Countries. Proceedings of the IBI International Symposium, Baghdad, 2-6 November 1975. North-Hollard Publishing Company, Amsterdam.

Pirow, P.C. (1985). Social Aspects of Computers in South Africa. In "Comparative Worldwide National Computer Policies" Proceedings of the Third IFIP TC9 Conference on Human Choice and Computers. (H. Sackman, ed.) North-Holland, Amsterdam.

Rigal, J.L. (1985). Informatization: Practices, and Standpoints in France. In "Comparative Worldwide National Computer Policies" Proceedings of the Third IFIP TC9 Conference on Human Choice and Computers. (H. Sackman, ed.) North-Holland, Amsterdam.

Roach, S. (1985). The New Technology Cycle. Economic Perspectives, Morgan Stanley (September 11, 1985); see also "White-Collar Productivity: A Glimer of Hope?" Special Economic Study, Morgan Stanley. (September 16, 1988); see also, "America's Technology Dilemma: A Pofile of the Information Economy." Special Economic Study, Morgan Stanley. (April 22, 1987).

Roche, E.M. (1980). From Sending a Runner to Sending a Telex: a History of Modern Communications. In "World Progress Through International Telecommunications: A Salute to the International Telecommunications Union." UNA-USA. New York.

Roche, E.M. (1981/2). Communications -- Missing Element in the New World Information Order. Journal of International Affairs, 35 (2), pp. 272-277.

Roche, E.M. (1991a). Brazilian Informatics Policy: The High Costs of Building a National Computer Industry. Information Society.

Roche, E.M. (1991b). "Telecommunications and Business Strategy." The Dryden Press, Chicago.

Roche, E.M. (1991c). "Managing Information Technology in Multinational Corporations: Theory, Measurement and Reality in the Global Environment." Macmillan, New York.

Rogers, E.M. and J.K. Larsen (1984). "Silicon Valley Fever: Growth of High-Technology Culture." Basic Books, Inc. New York.

Saunders, R.J. (1982). Telecommunications in Developing Countries: Constraints on Development. In "Communication Economics and Development" (M. Jussawalla, and D.M. Lamberton, eds.) pp. 190210. Pergamon Policy Studies, Pergamon Press, Elmsford, New York.

Saunders, R.J., J.J. Warford and B. Wellenius (1983). "Telecommunications and Economic Development." A World Bank Publications, The Johns Hopkins University Press, Baltimore,

Schiller, H.I. (1973). "The Mind Managers: How The Master Puppeteers of Politics, Advertising, and Mass Communications Pull the Strings of Public Opinion." Beacon Press, Boston.

Schiller, H.I. (1981). "Who Knows: Information in the Age of the Eortune 500." ABLEX Publishing Corporation, Norwood, New Jersey. 
Schiller, H.I. (1984). Remote Sensing by Satellite: Global Hegemony or Social Utility. In "World Communications: A Handbook" (G. Gerbner, M. Siefert, eds.) Longman, New York and London.

Schware, R. (1989). The World Software Industry and Software Engineering: Opportunities and Constraints for Newly Industrialized Economies. World Bank Technical Paper Number 104. Washington, D.C.

Schware, R. (1989b). Public Domain Software for Development. Information Technology for Development 4 (3), pp. 677-686.

Schware, R. and A. Trembour (1985). Rethinking Microcomputer Technology Transfer to Third World Countries. Science and Public Policy 12 (1), pp. 15-20.

Schware, R. and Z. Choudhury (1988). Aid Agencies and Information Technology Development. Information Technology for Development 3 (2), pp. 145-158.

Simon, D.F. (1988). Integrating the Electronics Industry. The China Business Review (July-August), pp. 27-30.

Simon, D.F. (1989). China's Economy Confronts the Challenge of the Global Technological Revolution. Business in the Contemporary World (Spring), pp. 98-114.

Singham, A.W., Editor (1977). "The Nonaligned Movement in World Politics." Lawrence Hill \& Co., Westport, Connecticut.

Sohn, L.B. (1967). "Cases on United Nations Law." Second Edition (Revised). The Foundation Press, Inc., Brooklyn.

Stavrianos, L.S. (1981). "Global Rift: The Third World Comes of Age." William Morrow and Company, New York.

Sweezy, P.M. (1942, 1970). "The Theory of Capitalist Development: Principles of Marxian Political Economy." Modern Reader Paperbacks, New York and London.

United Nations (1979). "Everyone's United Nations: A Handbook on the United Nations, Its Structure, and Activities." Ninth Edition. United Nations, New York.

United Nations Centre on Transnational Corporations (UNCTC) (1983). Transborder Data Elows and Brazil. Prepared by the Special Secretariat of Informatics of the National Security Council of the Presidency of the Republic of Brazil in Co-operation with the Ministry of Communications of Brazil.

United States Trade Representative (1982). Trade Barriers to Telecommunications, Data and Information Services. Computer printout, Washington, D.C.

Vallee, J. (1982). "The Network Revolution: Confessions of a Computer Scientist." And/Or Press, Inc., Berkeley.

Wallerstein, I. (1976). "The Modern World System: Capitalist Agriculture and the Origins of the European World-Economy in the Sixteenth Century" Academic Press, New York.

Wallerstein, I. (1980). "The Modern World-System II: Mercantilism and the Consolidation of the European World-Economy, 1600-1750." Academic Press, New York.

Wang, B.L. (1990). Remove the Name of Copykindom. Information and Computer, (121), pp. 8-9.

Westin, A.F. and M.A. Baker (1972). "Databanks in a Free Society." Quadrangle Books, New York.

Williams, R. (1976). "Communications." Third Edition. Penguin Books, Harmondsworth, Middlesex.

World Bank (1988). "The World Bank Annual Report 1988." Washington, D.C. World Bank (1990). "Development in the Information Age: An Evolving Role for the World Bank." Discussion Draft. 
Yun, K. (1989). Crossing the Yellow Sea. The China Business Review (January-Eebruary), pp. $38-48$. 